\title{
BOARD DIVERSITY OR GENDER DIVERSITY? PERSPECTIVES FROM EUROPE, AUstralia AND SOUTH AFRICA
}

\author{
JeAN J DU PLESSIS \\ INGO SAENGER ${ }^{* *}$ \\ RICHARD FOSTER ${ }^{* * *}$
}

Board diversity has been a hot topic for several years. However, it is only in recent years that pertinent questions have been asked about what is actually meant by board diversity and what would constitute a board with an ideal diversity. In the past the debate on board diversity has always been dominated by the lack, or very low numbers, of females on boards. This has been a fact in most countries with sophisticated corporate law and corporate governance systems in place. The issue of female representation on boards still dominates the board diversity debate, but other forms of diversity, including age, cultural, nationality and race have also become part of the debate. The quest is to find answers to questions like whether a diversified board would be better, and whether diversified boards will ensure a better return for investors; in other words, whether there is a 'business case' to be made out to have diversity on a board. Many studies have been done, but the answer is still evasive. This is not totally unexpected as the criteria used for these studies differ and the circumstances and complexities of business are such that a final conclusion will probably never be reached. In this article we focus on the board diversity debate in Europe, Australia and South Africa - three completely different parts of the world. In addition we devote Part V to put the topic of board diversity in a broader context, but paying particular attention to gender diversity.

\footnotetext{
* BProc, LLB, LLM, LLD (UOFS); Professor of Law, Deakin University. This author would like to thank Helen Wood, Law Librarian, Deakin University for her assistance in identifying the bulk of the sources that formed the basis of the first draft of this article.

** DrJur (University of Marburg), DrJurHabil (University of Jena); Professor of Law and Chair Civil Law, Law of Civil Procedure and Corporate Law at the University of Muenster, Germany.

*** FCIS, FinstD, H Dip Co Law (Wits), H Dip Tax Law (RAU), PG Dip Corp Gov (RAU); Group Secretary of Old Mutual, Chairman of Institute of Directors of Southern Africa and Member of the King Committee on Corporate Governance in South Africa.
} 


\section{INTRODUCTION}

In this article we will focus on board diversity generally, but because of the importance of gender diversity, it is mentioned more often than other forms of board diversity. The general aim of this article is to give an overview of some of the arrangements in place to ensure board diversity in Europe, Australia and South Africa. The focus will also be on areas where progress has been made and the initiatives taken in Europe, Australia and South Africa to improve board diversity. It is, in fact, a very delicate balance to achieve if a company wants to get the board diversity right in order to ensure that the company performs optimally. Literature supports the view that having virtually no board diversity (ie, all directors are middle-aged men with only accounting backgrounds), or too much board diversity (ie, a board of six consisting of six different nationalities, coming from six different career backgrounds and varying in age from 18 years to 70 years) would be ideal. ${ }^{1}$ A good, well-motivated and considered board composition will achieve the best results, but achieving the right balance is challenging. $^{2}$

In Parts 2 to 4 of this article we focus on board diversity, including gender diversity, in Europe, Australia and South Africa. We have selected these jurisdictions because they represent some interesting and representative developments regarding board diversity in recent years, and perspectives from different parts of the world. European countries (most notably Norway) have taken the lead with mandatory gender quota legislation, but there are huge divides at the European Union (EU) level as well as among European countries on whether that is the best way to go. Developments in Australia are comparable to that in the United Kingdom and New Zealand. However, in Australia there is faster progress in appointing more women to the boards of listed companies than in most other countries where gender balance is addressed through voluntary codes of conduct and not mandatory gender quota legislation. South Africa is unique because of its statutory Black Economic Empowerment (BEE) legislation, which also indirectly promotes the appointment of black people on boards, thus promoting cultural diversity on boards. In Part 5 we deal with gender diversity and mandatory gender quotas specifically, but from a broader, non-country and non-jurisdiction specific point of view.

\footnotetext{
${ }^{1}$ See Australian Institute of Company Directors (AICD), Company Directors Course Material (AICD, 2010) Module 8, 39, citing Nancy Adler, International Dimensions of Organisational Behaviour (South Western, 2002) 142-5.

${ }^{2}$ See AICD, above $\mathrm{n} 1,40$.
} 


\section{EUROPE}

\section{A European Efforts at the National Level ${ }^{3}$}

In European countries the lack of diversity on company boards is widely perceived to be an issue that requires serious attention. Especially, as far as gender imbalance is concerned, a high degree of awareness is detectable in almost all European nations. Although this mutual understanding exists, the approaches to tackle the issue differ significantly. While aiming to promote (gender) diversity, countries face a choice between relying on soft measures such as corporate governance codes, and enacting statutory regulation that is usually in the form of gender quotas.

\section{$1 \quad$ Norway}

Norway, which is not an EU member state, has been a front runner for introducing mandatory gender quotas for certain companies. In 2003 the Norwegian Parliament amended the Public Limited Liability Companies Act 1997 (Norway) to ensure adequate participation of women on company boards, effectively prescribing that each sex represents at least $40 \%$ of board memberships. ${ }^{4}$ The 'board' affected by the quota requirements is the Styre, the sole board under the Norwegian one-tier system. ${ }^{5}$ The regulation, which gradually came into effect by the beginning of 2008, applies to publicly owned enterprises ${ }^{6}$ as well as to the approximately 450 public limited companies in the private sector in Norway. ${ }^{7}$ It is important to note that the quota requirements do not affect limited liability companies (there are about 200,000 of them in Norway). The abstinence from legislation in this field is explained by the fact that most of these companies are small family enterprises with the owners themselves being personally involved in managing the company. ${ }^{8}$ Potential consequences for disobeying the above-mentioned quotas are quite harsh:

\footnotetext{
3 The authors thank Alexander Scheuch (University of Muenster) for his assistance with the European part of this article.

${ }^{4}$ For an English-language summary of the specific requirements, see Norwegian Ministry of Trade and Industry <http://www.regjeringen.no/en/dep/nhd/press-centre/fact-sheets/fact-sheetthe-legislation-on-representa.html?id=641431>.

${ }^{5}$ Cf Sebastian Balzter, 'Goldröcke und Großmütter an der Macht', FAZ (online), 15 February 2011, $18<$ <ttp://www.faz.net/aktuell/wirtschaft/norwegens-frauenquote-goldroecke-undgrossmuetter-an-der-macht-1590587.html>.

${ }^{6}$ Public Limited Liability Companies Act 1997 (Norway) (Lov om aksjeselskaper (aksjeloven)) s 20-6-15.

${ }^{7}$ Ibid s 6-11a.

${ }^{8}$ Cf Norwegian Ministry of Children, 'Equality and Social Inclusion’ (Media Release, 2010) $<$ http://www.regjeringen.no/en/dep/bld/whats-new/Speeches-and-articles/minister/taler-ogartikler-av-barne--likestilling/2010/Global-Roundtable-on-Board-Diversity.html?id=599588 > .
} 
registration of a company board will be refused by the responsible authorities in cases where the board's composition does not meet the statutory requirements and such companies may be dissolved by court order. ${ }^{9}$ In light of these enforcement rules, it was not surprising that the percentage of women on Norwegian company boards rose significantly within a short period of time. ${ }^{10}$ In a study undertaken by Deloitte it was discovered that by the end of 2010, 31.9\% of the positions on the largest ASA company boards in Norway were filled by women, while $35.6 \%$ of such positions were filled by women in a sample of 25 listed companies researched by Deloitte. Thus, although not at the required aspiration of $40 \%$ women on boards by 1 January 2008, the percentage is significantly higher than in any other country Deloitte included in their study. ${ }^{11}$ On the other hand, it is interesting to note that in 2011 the CEOs of the 20 largest Norwegian companies were still all male. ${ }^{12}$

\section{France}

France is another country that has gained quite a bit of public attention for enacting legislative rules on female board representation. It is very interesting to retrace the development that led to this legislation. The French AFEP MEDEF Corporate Governance Code of Listed Corporations was only amended in April 2010 to increase the presence of women on boards. ${ }^{13}$ Under a 'comply or explain' regime, ${ }^{14}$ the code (among other rules regarding gender balance) now sets forth the objective that each board shall reach a minimum percentage of $40 \%$ women within a period of six years after the publication of the rule or the listing of the company's shares. ${ }^{15}$ Although within a year of the new provision of the code coming into effect a rise in female participation on boards was already apparent, ${ }^{16}$ France nonetheless decided to enact a law concerning the

\footnotetext{
${ }^{9}$ Public Limited Liability Companies Act 1997, above n 6, s 16-15 (1 ${ }^{\text {st }}$ para, no 2).

${ }^{10}$ Balzter, above $\mathrm{n} 5$.

${ }^{11}$ See The Deloitte Global Centre for Corporate Governance, Women in the Boardroom: A Global Perspective (November 2011) 21 $<$ http://www.corpgov.deloitte.com/binary/com.epicentric.contentmanagement.servlet.ContentDe liveryServlet/USEng/Documents/NominatingCorporate\%20Governance\%20Committee/Board\%20Composition\%20and\%20Recruitment/Wo men\%20in\%20the\%20Boardroom_Deloitte_111511.pdf>.

${ }^{12}$ Balzter, above $\mathrm{n} 5$.

13 See English-language version, Association Française des Entreprises Privées, Corporate Governance Code of Listed Corporations (April 2010) $<$ http://www.medef.com/fileadmin/www.medef.fr/documents/AFEP-MEDEF/Guide_AFEPMEDEF_An_18-11.pdf >.

${ }^{14}$ Ibid art 22.

${ }^{15}$ Ibid art 6.3 ( $2^{\text {nd }}$ para).

16 See Raphäle François-Poncet, Barbara Deilmann and Sabine Otte, 'Frauenquote in französischen Aufsichts - und Verwaltungsräten - ist eine Quote auch in Deutschland zulässig?' (2011) 14 NZG 450, 451.
} 
equal representation of men and women on administrative and supervisory boards $^{17}$ on 27 January 2011. ${ }^{18}$ The French law requires a percentage of at least $40 \%$ of each sex on the boards of publicly listed companies and companies of a certain size (depending on the number of employees and annual revenue/profits). ${ }^{19}$ The threshold has to be reached by January 2017. Failure to fulfil the requirements will not have the same rigorous consequences as in Norway, but the impact will still be considerable. An appointment of board members in violation of the quota will be void. ${ }^{20}$ However, resolutions by a board that is not composed in accordance with the statutory provisions will still be effective. $^{21}$ Attendance fees for board members may not be paid until a lawful composition of the board is reached. ${ }^{22}$ So far, judging by the numbers, the law has had the desired effect: the share of women on the boards of the largest publicly listed companies in France increased from 12.3\% in October 2010 to $22.3 \%$ in January 2012 . $^{23}$

\section{Other Countries with Quota Legislation}

While Norway and France might have gained the most public attention for their actions, there are other prominent examples of gender quota legislation in Europe. Belgium, ${ }^{24}$ Italy, Spain and the Netherlands, among others, have followed the same path in adopting comparable rules. ${ }^{25}$

The national rules vary in details but usually require around 30\% to $40 \%$ female board members. The companies affected by the rules vary by country but usually include state-owned and publicly listed companies as well as other large companies. Typically, a transition period of about five years is set to allow for the necessary adjustments. Enforcement strategies range from heavy sanctions,

17 Under French law there is a choice between a one-tier and a two-tier board system when establishing a public company.

${ }^{18}$ Loi $n^{\circ}$ 2011-103 relative à la représentation équilibrée des femmes et des hommes au sein des conseils d'administration et de surveillance et à l'égalité professionnelle.

${ }^{19}$ Code de Commerce [French Commercial Code] s L225-18-1 ( $1^{\text {st }}$ para).

${ }^{20}$ Ibid s L225-18-1 ( $2^{\text {nd }}$ para, $1^{\text {st }}$ sentence).

${ }^{21}$ Ibid s L225-18-1 ( $2^{\text {nd }}$ para, $2^{\text {nd }}$ sentence). See also François-Poncet et al, above n 16, 453.

22 See François-Poncet et al, above n 16, 453; Martin Henssler and Thomas Seidensticker, 'Eckdaten einer verfassungs - und europarechtskonformen Ausgestaltung verbindlicher Frauenquoten für Aufsichtsräte’ (2012) 3 KSzW 10, 11.

${ }^{23}$ European Commission, 'European Commission Weighs Options to Break the "Glass Ceiling” for Women on Company Boards' (Press Release, IP/12/213, 5 March 2012) 5 ('EC Press Release IP/12/213’).

24 Note, 'Frauenquote in Belgien’, FAZ, 18 June 2011 (Nr 140) 12.

${ }^{25}$ For a list of ‘quota nations' in March 2012, see EC Press Release IP/12/213, above n 23, 2. See also The Deloitte Global Centre for Corporate Governance, above n 11, 21. 
such as monetary fines and dissolution of the board, to mere incentives like preferential treatment in the awarding of contracts. ${ }^{26}$

\section{Germany}

Europe's largest economy, Germany, is naturally at the centre of attention when it comes to economic legislation. Searching for rules regarding board diversity in the Stock Corporation Act 1965 (Germany) [Aktiengesetz (AktG)], reveals that there are no such rules nor any provisions on board diversity. To be in a position to evaluate the lack of statutory provisions governing board diversity, one needs to become familiar with some peculiar features of German company law first. Three organs are required for German public companies (AGs). They are the general meeting (Hauptversammlung), the supervisory board (Aufsichtsrat) and the management board (Vorstand). This means that a two-tier board system is in effect, with the management board managing and directing the corporation, and the supervisory board being responsible for overseeing the management and appointing and removing members of the management board. For private companies (Gesellschaften mit beschränkter Haftung (GmbHs)), only two organs are required: the management organ (comparable to the management board in the AG), and the organ for the corporators (comparable to the general meeting in the AG), ${ }^{27}$ but co-determination legislation also makes a supervisory board compulsory for some larger GmbHs. ${ }^{28}$

There has been a long history of employee participation at supervisory board level, also called co-determination, in Germany. The concept of supervisory co-determination and the concept of the two-tier board system in Germany developed separately, but are now almost inextricably linked. Whether employee representation on a board is mandatory generally depends on the number of employees the company has, with some special rules applying in the coal and steel industry. ${ }^{29}$ For companies with more than 2,000 employees, as a general rule, half of the supervisory board members must be employee representatives whereas the other half is composed of shareholder representatives. The chairperson of the supervisory board is elected from the

\footnotetext{
${ }^{26}$ For a critical view of the sanctions (or rather the lack thereof) introduced by the Dutch law, see Tineke Lambooy, 'Thirty Percent of Women on Boards; New Law in the Netherlands' (2012) 9 ECL 53.

${ }^{27}$ Friedrich Kübler and Heinz Dieter Assmann, Gesellschaftsrecht (Müller Verlag, $6^{\text {th }}$ ed, 2006) 261. See also Jean J du Plessis, Bernhard Großfeld, Claus Luttermann, Ingo Saenger, Otto Sandrock and Matthias Casper, German Corporate Governance in International and European Context (Springer Verlag, 2012) 55-6.

${ }^{28}$ Kübler and Assmann, above n 27, ch 5; Du Plessis et al, above n 27, 155-61.

${ }^{29}$ For a detailed overview of the different scenarios, see Ingo Saenger, Gesellschaftsrecht (Verlag Franz Vahlen, 2010) 578.
} 
latter group and has a casting vote. ${ }^{30}$ It is clear that co-determination provisions act as a 'natural source' of board diversity by ensuring that in many companies there is a significant number of employee and union representatives ${ }^{31}$ who, of course, often tend to have a background different from that of shareholder representatives. ${ }^{32}$ In addition, one of the laws governing co-determination states that the proportion of male/female employee representatives 'shall' mirror the respective proportion of all employees. ${ }^{33}$ It should not be omitted, however, that co-determination can also have a negative effect on board diversity. This holds true as far as nationality diversity is concerned. Unsurprisingly, employee representatives are primarily of German nationality. This is evidenced by a study which found that nationality diversity among supervisory boards is much lower than on management boards. ${ }^{34}$ Generally, international diversity on German boards is extremely low compared to other nations. ${ }^{35}$

Besides these factors concerning board diversity that come along with the system of co-determination, there are also 'soft rules' — as opposed to legislative requirements - in Germany regarding the subject. They are to be found in the German Corporate Governance Code (GCGC) in the section dealing with the supervisory board. The code, whose content is backed by a 'comply or explain' provision in the German Stock Corporations Act, ${ }^{36}$ in its most recent version dating from 2010, now provides as follows:

When appointing the Management Board, the Supervisory Board shall also respect diversity and, in particular, aim for an appropriate consideration of women. $^{37}$

The Supervisory Board shall specify concrete objectives regarding its composition which, whilst considering the specifics of the enterprise, take into account ... diversity. These concrete objectives shall, in particular, stipulate an appropriate degree of female representation. Recommendations by the Supervisory Board to the competent election bodies shall take these objectives

\footnotetext{
${ }^{30}$ See Mitbestimmungsgesetz (Germany) [Codetermination Act] 1976, ss 27, 29 ( $2^{\text {nd }}$ para).

${ }^{31}$ Regarding the latter group, ibid, s 7 ( $2^{\text {nd }}$ para).

${ }^{32}$ Cf Heribert Hirte, ‘Geschlechterquoten in Aufsichtsrat und Vorstand' (2011) 9 Der Konzern 519, 522.

${ }^{33}$ Drittelbeteiligungsgesetz (Germany) [One-Third Participation Act] 2004, 2, 4 (4 $4^{\text {th }}$ para).

${ }^{34}$ See Kees van Veen and Janine Elbertsen, 'Governance Regimes and Nationality Diversity in Boards: A Comparative Study of Germany, the Netherlands and the United Kingdom' (2008) 16 Corporate Governance: An International Review 386, 384. The authors explain this peculiarity of the German supervisory board very well at 389-90.

35 European Commission, Green Paper - The EU Corporate Governance Framework (COM(2011), 5 April 2011, 164 final) ('EC Green Paper 2011') [1.1.2].

${ }^{36}$ Stock Corporations Act 1965 (Germany), s 161 ( $1^{\text {st }}$ para, $1^{\text {st }}$ sentence).

${ }^{37}$ GCGC art 5.1.2 ( $1^{\text {st }}$ para, $2^{\text {nd }}$ sentence $)$.
} 
into account. The concrete objectives of the Supervisory Board and the status of the implementation shall be published in the Corporate Governance Report. $^{38}$

As seen, the provisions regarding diversity apply to the composition of both tiers of the board. However, they can hardly be called strict taking into account that — different from the French Code — no set quota is given.

An analysis of the annual reports issued by the 30 major German stock companies that was conducted in 2011 brought to light that 24 of those companies had set a target for women's participation in the supervisory board — either stating absolute numbers or a certain percentage. ${ }^{39}$ The realisation of these goals has proceeded rather slowly, though. The most recent inspection of 160 German listed corporations from October 2012 found women made up only $15.32 \%$ of all supervisory board members. ${ }^{40}$ The percentage of female shareholder representatives is even lower, with only $10.6 \%$ being women; ${ }^{41}$ whereas women accounted for $22.82 \%$ of employee representatives, ${ }^{42}$ which is, to a large extent, explained by the aforementioned provisions in German codetermination law. ${ }^{43}$ The numbers for the management board are even more blatantly disproportionate. Only $4.08 \%$ of management board members are females. ${ }^{44}$ While looking at these numbers, one should keep in mind that supervisory board members serve a maximum term of five years ${ }^{45}$ which naturally slows down the rate of changes.

${ }^{38}$ Ibid art 5.4.1 ( $2^{\text {nd }}$ and $3^{\text {rd }}$ para). For further comment on this rule and for consequences of violation see Daniela Weber-Rey and Friederike Handt, 'Vielfalt/Diversity im Kodex Selbstverpflichtung, Bemühenspflicht und Transparenz' (2011) 14 NZG 1; Claudia Schubert and Gönke Jacobsen, 'Personelle Vielfalt als Element guter Unternehmensführung — die Empfehlung des Corporate Governance Kodex und die Rechtsfolgen ihrer unzureichenden Berücksichtigung’ (2011) 65 WM 726.

${ }^{39}$ PricewaterhouseCoopers, 'DAX30: Nur 67 Frauen unter 500 Aufsichtsratsmitgliedern' (Press Release, 29 March 2012) <http://www.pwc.de/de/pressemitteilungen/2011/dax30-nur-67-frauenunter-500-aufsichtsratmitgliedern.jhtml>.

40 Fidar eV, Women-on-Board-Index $\quad(14 \quad$ October 2012 $) \quad 15$ $<$ http://www.fidar.de/webmedia/documents/wob-index/121014_Studie_WoBIndex_IX_end.pdf $>$.

${ }^{41}$ Ibid 17.

${ }^{42}$ Ibid 18.

43 Henssler and Seidensticker, above n 22, $10 \mathrm{n} \mathrm{1;}$ Marcus Schladebach and Georgia Stefanopoulou, 'Frauenquote in Aufsichtsräten - Überlegungen zur Änderung des Aktienrechts' (2010) 65 BB 1042, 1044; Gerald Spindler and Kathrin Brandt, 'Verfassungsrechtliche Zulässigkeit einer Gleichstellungsquote im Aufsichtsrat der börsennotierten AG’ (2011) 14 NZG 401.

${ }^{44}$ Fidar eV, above n 40, 19.

${ }^{45}$ German Stock Corporations Act, above n 36, s 102 (1 $1^{\text {st }}$ para). 
In the face of this data, there have been initiatives pushing for quota regulation in Germany. Proposals for legislative acts have included a quota of $40 \%$ for supervisory boards of listed companies and companies subject to codetermination, ${ }^{46}$ an additional quota of $30 \%$ for management boards, ${ }^{47}$ and even a $50 \%$ quota for women in both tiers of the board of all stock corporations and some other companies. ${ }^{48}$ The most detailed proposals have been introduced to the Bundesrat (Federal Council, the 'upper house' of the German parliament) by the states of North Rhine-Westphalia ${ }^{49}$ and Hamburg. ${ }^{50}$ If these were to become law, publicly listed companies would be required eventually to reach a quota of $40 \%$ by 2022 or 2023 (subject to a hardship clause). Under the North RhineWestphalia draft, the selection of a supervisory board member violating the quota requirements would be void. Choosing a different approach, the Hamburg draft contains a kind of penalisation by refusing tax deductibility for the remuneration of the supervisory board members.

All of these propositions, however, have either been rejected outright ${ }^{51}$ or not taken on board (yet). Currently, consensus does not even exist in the German government, with the Minister of Labour and Social Affairs supporting quota

46 Alliance, 90/The Greens, Draft of a Law for the Equal Representation of Genders on Supervisory Boards [2010] BT-Drucksache 17/3296 (Parliamentary Documentation of the German Bundestag) <http://dipbt.bundestag.de/dip21/btd/17/032/1703296.pdf>; Social Democratic Party, Motion to Enact Quota Law for Supervisory Boards and Management Boards [2011] BT-Drucksache 17/4683 (Parliamentary Documentation of the German Bundestag) $<$ http://dipbt.bundestag.de/dip21/btd/17/046/1704683.pdf >. The same approach is taken by the working group on female lawyers of the German lawyers' association (DAV) - see Barbara Mayer, 'Vier Thesen für die Frauenquote in Aufsichtsräten' (2011) 61 AnwBl 919 $<$ http://anwaltverein.de/leistungen/Anwaltsblatt/Archiv>.

${ }^{47}$ Mayer, above n 46, 919.

48 The Left, Motion Regarding the Equal Representation of Genders in Leading Positions in Businesses [2011] BT-Drucksache 17/4842 (Parliamentary Documentation of the German Bundestag) <http://dipbt.bundestag.de/dip21/btd/17/048/1704842.pdf > .

${ }^{49}$ Draft of a Law for the Promotion of Equality of Women and Men on Supervisory Boards of Public Listed Companies (FöGAbUG) [2011] BR-Drucksache 87/11 (Official Document of the German Bundesrat) $<$ http://www.bundesrat.de/cln_320/nn_2034972/SharedDocs/Drucksachen/2011/0001-0100/8711,templateId=raw,property=publicationFile.pdf/87-11.pdf> ('FöGAbUG, BR-Drucksache 87/11').

${ }^{50}$ Draft of a Law for the Promotion of Equal Participation of Women and Men in Top Management Positions (Entwurf eines Gesetzes zur Förderung gleichberechtigter Teilhabe von Frauen und Männern in Führungsgremien, GlTeilhG) [2012] BR-Drucksache 330/12 (Official Document of the German Bundesrat) <http://www.bundesrat.de/cln_320/nn_8336/SharedDocs/Drucksachen/2012/0301-400/33012,templateId=raw,property=publicationFile.pdf/330-12.pdf $>$.

51 The above-mentioned motion by The Left party was rejected by the Bundestag Legal Committee in February of 2012. 
legislation ${ }^{52}$ and the Minister of Family Affairs, Senior Citizens, Women and Youth opposing it. ${ }^{53}$ Chancellor Angela Merkel so far has sided with the latter, ${ }^{54}$ but there have been rumours about a change of mind. ${ }^{55}$ Even if that is the case, she would face stiff opposition from her current coalition partner, the liberal Free Democrats, who have already prevented legislation that would allow for companies to set their own quotas. ${ }^{56}$

\section{B Efforts at the EU Level}

In Europe the discussion on ways to promote diversity on corporate boards has not been limited to the national level. EU institutions have also dealt with the topic and EU leaders have voiced their opinions, especially on the subject of women's presence on boards. EU Justice Commissioner, Viviane Reding, has turned out to be a particular 'driving force' behind the movement. She has repeatedly stressed the economic advantages connected to women's participation in boardrooms. ${ }^{57}$ In March of 2011, Ms Reding, following a meeting with business leaders, announced that she would give 'self-regulation a last chance' ${ }^{58}$ She called on all publicly listed companies in Europe to sign a pledge to increase women's presence on corporate boards to 30\% by 2015, and to $40 \%$ by 2020 . Barely concealed was her threat to use her 'regulatory creativity, ${ }^{59}$ as ultima ratio $^{60}$ if significant progress should not become visible within a year's time. Commissioner Reding's approach was welcomed by the European Parliament. In a resolution of 6 July $2011^{61}$ the EP urged companies to reach said thresholds by the proposed dates, and strongly supported the announcement of European legislation in case voluntary measures should prove to be insufficient to accomplish these goals. In this case the Parliament proposed

${ }^{52}$ Ursula von der Leyen, as quoted in 'Leyen will ein Drittel Frauen in Vorständen', FAZ, 30 March 2011 (Nr 75) 11.

${ }^{53}$ Kristina Schröder, as quoted in ibid 11.

54 Cf Kathrin Brandt and Alexander Thiele, 'Zulässigkeit einer Gleichstellungsquote im Aufsichtsrat unter Berücksichtigung der Rechtsprechung des EuGH’ (2011) 56 AG 580, 581.

55 'Merkel liebäugelt mit der Frauenquote', Spiegel (online), 11 March 2012 $<$ http://www.spiegel.de/politik/deutschland/0,1518,820647,00.html>.

56 See 'Frauenaufstand gegen Schröder', Spiegel (online), 6 March 2012 $<$ http://www.spiegel.de/politik/deutschland/0,1518,819638,00.html>.

57 See eg, European Commission, 'EU Justice Commissioner Reding Challenges Business Leaders to Increase Women's Presence on Corporate Boards with "Women on the Board Pledge for Europe"' (MEMO/11/124) 1: '[More women on boards] can make companies more profitable and trigger sustainable economic growth'.

${ }^{58}$ Ibid.

${ }^{59}$ Ibid.

${ }^{60}$ Viviane Reding, 'Gesetzliche Frauenquote?’ (2011) 44 ZRP 127.

61 European Parliament Resolution of 6 July 2011 on Women and Business Leadership (2010/2115(INI)) ('Resolution on Women and Business Leadership'). 
quotas while recognising, however, the need to take into account the economic, structural, legal and regional specificities of the EU Member States. Company size was given as an example of such factors. On 5 March 2012 Commissioner Reding offered an evaluation of developments in the previous year. She expressed her disappointment about the 'stubbornly slow' change and the 'persistent lack of gender diversity in boardrooms', revealing that only 24 companies across Europe had signed the aforementioned pledge. ${ }^{62}$ In reaction to this, Ms Reding announced the launch of public consultation that ran until the end of May 2012 seeking views on possible (legislative) action at EU level. ${ }^{63} \mathrm{At}$ the same time, the Commissioner released data indicating that there had been, at best, limited progress. The share of women on the boards of the largest publicly listed companies in the EU rose from 11.8\% in October 2010 to 13.7\% in January 2012 - the aforementioned developments in France accounting for around half the increase. ${ }^{64}$ It is striking that all Scandinavian EU members find themselves among the top group of countries when it comes to board diversity, while fellow Nordic nations, Iceland (25\%) and Norway (42\%) top the list of European non-EU countries. ${ }^{65}$ The Commissioner also pointed out that a survey conducted in all EU countries found that $75 \%$ of Europeans are in favour of gender balance legislation regarding company boards. ${ }^{66}$ A recent research report, as part of McKinsey's 'Women Matter' series, found that $63 \%$ of the 235 large European companies surveyed have at least 20 different initiatives in place as part of their gender diversity program, but still women accounted for more than a quarter of the top jobs in only $8 \%$ of companies in the survey. ${ }^{67}$ The most recent reports predict that before long the EU commission will present a draft for an EU directive that aims at a mandatory quota of $30 \%$ by 2015 , and $40 \%$ by $2020 .^{68}$

\section{Influence of National Constitutional Law and EU law}

The influence of EU treaties and national constitutional law on the quota debate is double-edged. On the one hand, both national constitutions and EU law demand, in one or other form, equality of men and women as a guiding

${ }^{62}$ EC Press Release IP/12/213, above n 23, 2.

${ }^{63}$ Ibid 1.

${ }^{64}$ Ibid $2-5$.

${ }^{65}$ Ibid 4. See, however, Deloitte, above n 11, 21 for slightly different statistics.

${ }^{66}$ EC Press Release IP/12/213, above n 23, 7.

${ }^{67}$ McKinsey \& Company, Women Matter 2012 - Making the Breakthrough (March 2012) 3 $<$ http://www.mckinsey.com/ /media/mckinsey/dotcom/client_service/Organization/PDFs/Wom en_matter_mar2012_english.ashx>.

${ }^{68}$ Editorial, ‘Reding Will Europaweite Frauenquote Durchdrücken’, Financial Times Deutschland (online), 14 June $2012<$ http://www.ftd.de/karriere-management/karriere/:gleichberechtigungreding-will-europaweite-frauenquote-durchdruecken/70050363.html> . 
principle ${ }^{69}$ and as a fundamental right. ${ }^{70}$ This fact is stressed by supporters of quota legislation ${ }^{71}$ who can also invoke, for their purposes, EU and national rules that allow for the adoption of measures providing for specific advantages in favour of the underrepresented sex, for example, to compensate for disadvantages in professional careers. ${ }^{72}$

On the other hand, demanding the appointment of a certain number of board members from each sex can also affect the fundamental rights of candidates of the opposite sex, of the corporation and its shareholders. Using the example of the German Constitution, a quota for females could, at least in the case of a male candidate with superior qualifications, ${ }^{73}$ potentially violate the right to equality $^{74}$ and the occupational freedom ${ }^{75}$ of male candidates. Some commentators have warned against 'collateral damage' of quotas in the form of a possible decrease in motivation of talented male candidates. ${ }^{76}$ Caution is also advisable with regard to the company's perspective and its shareholders' point of view: fundamental rights that could be affected are freedom of association, ${ }^{77}$ the guarantee of property ${ }^{78}$ and, again, occupational freedom. It is also argued that quota laws would further jeopardise the shareholders' freedom of choice in appointing board members - a freedom already limited by co-determination and independence requirements. ${ }^{79}$ In addition, some authors ${ }^{80}$ are of the opinion that national quota laws would violate European fundamental freedoms, namely,

${ }^{69}$ Treaty on European Union [2010] OJ C 83/13, art 3 ( $3^{\text {rd }}$ para, $2^{\text {nd }}$ sub-para); Treaty on the Functioning of the European Union [2010] OJ C 83/49, art 8.

${ }^{70}$ Charter of Fundamental Rights of the European Union [2000] OJ C 364/01, art 23 (1 $1^{\text {st }}$ para). For national constitutional law see Grundgesetz für die Bundesrepublik Deutschland [Basic Law of the Federal Republic of Germany] s 3 ( $2^{\text {nd }}$ para, $1^{\text {st }}$ sentence $)$.

${ }^{71}$ FöGAbUG, BR-Drucksache 87/11, above n 49, 16; Mayer, above n 46, 919.

${ }^{72}$ Charter of Fundamental Rights of the European Union, above n 70, art 23 ( $2^{\text {nd }}$ para); Treaty on the Functioning of the European Union, above n 69, art 8. See also Basic Law of the Federal Republic of Germany, above $n 70$, art 3 ( $2^{\text {nd }}$ para, $2^{\text {nd }}$ sentence), which allows for steps to eliminate existing disadvantages.

${ }^{73}$ Schladebach and Stefanopoulou, above n 43, 1046; Gerd Krieger, 'Keine Gesetzliche Frauenquote für Aufsichtsräte' (2011) 61 AnwBl 918.

${ }^{74}$ Basic Law of the Federal Republic of Germany, above $n 70$, s 3 ( $2^{\text {nd }}$ and $3^{\text {rd }}$ para).

${ }^{75}$ Ibid, s 12 (1 $1^{\text {st }}$ para).

${ }^{76}$ Michael Kempter, 'Gesetzliche Frauenquote?’ (2011) 44 ZRP 219, 220.

${ }^{77}$ Basic Law of the Federal Republic of Germany, above $\mathrm{n} 70$, art 9 ( $1^{\text {st }}$ para). This is mentioned in particular by François-Poncet et al, above n 16, 454.

${ }^{78}$ Basic Law of the Federal Republic of Germany, above n 70, s 14 ( $1^{\text {st }}$ para).

${ }^{79}$ See the expert opinion prepared for the Association of German Jurists by Mathias Habersack, 'Staatliche und halbstaatliche Eingriffe in die Unternehmensführung - Gutachten E', Verhandlungen des 69 (Deutschen Juristentages München 2012, Vol 1, 2012) 42.

${ }^{80}$ See Schladebach and Stefanopoulou, above n 43, 1045. 
the right of establishment ${ }^{81}$ and the freedom of movement of capital, ${ }^{82}$ although this assessment is rejected by others. ${ }^{83}$

This article does not intend to give an in-depth analysis of the situation from an EU or constitutional law perspective, which would require the specificities of the individual countries to be taken into account. Rather, it merely attempts to point out some of the potential problems and to raise awareness of the constitutional questions. The existence of constitutional problems has become obvious in France, for example, where a constitutional amendment was necessary in 2008 to pave the way for quota legislation. The French Constitution in its updated version now states as follows:

Statutes shall promote equal access by women and men to elective offices and posts, as well as to positions of professional and social responsibility. ${ }^{84}$

Regarding the situation in Germany, in a detailed analysis of the constitutional situation, the former President of the German Federal Constitutional Court has come to the conclusion that a legally binding women's quota would be constitutional in principle, but would be unconstitutional pertaining to companies in which women are generally underrepresented. ${ }^{85}$

\section{Outlook and Concerns Regarding EU Legislation}

Having established the factual and legal situation in European countries and having described some of the underlying arguments concerning quota legislation, one can now venture to take a closer look at legislative quota rules that might be adopted in the future.

\section{Scope of Potential Rules}

No matter whether one is thinking of measures on the national or on the EU level, there is always the question of how broad the rules can or should be; that is, the scope of application needs to be defined.

The first question deals with what kind of companies should be subjected to a quota regime. A case can certainly be made out for including all publicly listed

\footnotetext{
${ }^{81}$ Treaty on the Functioning of the European Union, above n 69, art 49.

${ }^{82}$ Ibid art 63.

${ }^{83}$ See Hans-Jürgen Papier and Martin Heidebach, 'Die Einführung einer gesetzlichen Frauenquote für die Aufsichtsräte deutscher Unternehmen unter verfassungsrechtlichen Aspekten’ (2011) 40 ZGR 305, 329ff.

${ }^{84}$ La Constitution du 4 octobre 1958 [French Constitution] s 1 ( $\left({ }^{\text {nd }}\right.$ para).

${ }^{85}$ Papier and Heidebach, above n 83, 305ff.
} 
companies. ${ }^{86}$ They are typically large and due to their special position serve as a 'role model' for other enterprises. ${ }^{87}$ In addition to that, shareholders of listed companies themselves do not usually assume the role of active involve in managing the company's business ${ }^{88}$ which - as already mentioned in the context of Norwegian legislation - is different in most smaller private companies, and serves as a strong argument for the exclusion of these smaller private companies from quota requirements. In addition to listed corporations, one can also think about adding companies of a certain minimum size to the list of quota-regulated enterprises, ${ }^{89}$ although some authors deem the number of shareholders to be decisive rather than the size of the company. ${ }^{90}$ Finally, it could be argued that a coherent approach to quota requirements (whether through soft law or hard law) should, under normal circumstances, always include state-owned enterprises and public institutions. ${ }^{91}$

After having determined which companies must obey the quota, in some countries it must further be determined which organ the quota requirement should apply to. This affects countries where a two-tier board system is in place. In the German discussion, some interesting arguments have surfaced in favour of limiting quotas solely to the supervisory board - not just because, in general terms, it seems to be a more careful and considerate approach, whereas, including the management board might go beyond what is necessary. ${ }^{92}$ Also, as noted above, the supervisory board appoints the management board members. By enhancing the number of female supervisory board members, the reasoning goes, the number of women on the management board will indirectly be increased, as female supervisory board members will appoint more females. ${ }^{93}$ Furthermore, a quota rule, at least in Germany, seems to fit better into existing rules concerning the supervisory board than into those regarding the management board. ${ }^{94}$

${ }^{86}$ This view is sometimes criticised for the alleged lack of a connection between listing and the specific quotas required for listed companies - see the expert opinion prepared for the Association of German Jurists by Habersack, above n 79, 41.

${ }^{87}$ FöGAbUG, BR-Drucksache 87/11, above n 49, 26; Henssler and Seidensticker, above n 22, 17.

${ }^{88}$ FöGAbUG, BR-Drucksache 87/11, above n 49, 26; Henssler and Seidensticker, above n 22, 16. Also emphasising the divergence between principals and agents, see: Katja Langenbucher, 'Frauenquote und Gesellschaftsrecht' (2011) 66 JZ 1038, 1040.

${ }^{89}$ For details, see Langenbucher, above n 88, $1041 \mathrm{ff}$.

${ }^{90}$ Henssler and Seidensticker, above n 22, 16.

${ }^{91}$ Cf Krieger, above n 73, 918.

${ }^{92}$ FöGAbUG, BR-Drucksache 87/11, above n 49, 27. This view is shared by Gregor Bachmann, 'Zur Umsetzung einer Frauenquote im Aufsichtsrat' (2011) 32 ZIP 1131, $1138 \mathrm{ff}$.

${ }^{93}$ FöGAbUG, BR-Drucksache 87/11, above n 49, 2.

${ }^{94}$ See Langenbucher, above n 88, $1043 \mathrm{ff}$. 
Another important question concerning the scope of quota regulation relates to sanctions. Quite a few possible approaches come to mind. In a survey, European citizens expressed their preference for monetary fines in case companies fall short of the quota (49\% of all participants mentioned this as an effective sanction). ${ }^{95}$ Other commonly mentioned possibilities include the refusal of public grants (30\% in favour), the annulment of the nomination of members of the overrepresented gender (28\%), the annulment of board decisions (28\%) and the deregistration of the company (10\%). ${ }^{96}$ An extreme sanction, such as the deregistration of the company, may lead to quicker results (see Norway) but raises strong doubts about its consistency with the principle of proportionality ${ }^{97}$ and has even been called a 'grotesque' consequence. ${ }^{98}$ This is also true of the threat of delisting the company. ${ }^{99}$ Sometimes the same is said of the annulment of board decisions, ${ }^{100}$ although this case is not as clear-cut. One has to concede, however, that this might make necessary an action for nullification which clashes with the principle of legal certainty and could, at the same time, give rise to vexatious litigants. ${ }^{101}$ Hence, nullification of board decisions does not seem like an ideal solution. Even the Constitutional Court of Belgium expressed constitutional concerns about the first version of a quota law that included the sanction of nullification of board decisions. ${ }^{102}$ Monetary fines, on the other hand, are also accompanied by a serious problem since they might be viewed as an incentive for the company to buy its way out of having to respect the quota. $^{103}$

Other questions regarding the scope of possible rules concern the exact percentage (eg, $30 \%$ or $40 \%$ ) and the existence and scope of exceptions to the rule, for example, hardship clauses. They shall not be discussed here but are sufficiently explored elsewhere. ${ }^{104}$

\section{Questions Regarding EU Competence}

Even if one could find satisfactory answers to all the questions presented about the scope of a quota law, one would still have to decide whether quota

\footnotetext{
${ }^{95}$ EC Press Release IP/12/213, above n 23, 7.

${ }^{96}$ Ibid.

${ }^{97}$ FöGAbUG, BR-Drucksache 87/11, above n 49, 21.

${ }^{98}$ Krieger, above n 73, 918.

${ }^{99}$ Spindler and Brandt, above n 43, 404; Bachmann, above n 92, 1138.

${ }^{100}$ Krieger, above n 73, 918.

${ }^{101}$ FöGAbUG, BR-Drucksache 87/11, above n 49, 20-1. Cf Bachmann, above n 92, 1138; Hirte, above $\mathrm{n} 32,528$ is critical of this approach.

${ }^{102} \mathrm{Cf}$ 'Frauenquote in Belgien', above n 14, 12.

${ }^{103}$ FöGAbUG, BR-Drucksache 87/11, above n 49, 21.

${ }^{104}$ See, eg, Bachmann, above n 92, 1137; Henssler and Seidensticker, above n 22, $13 \mathrm{ff}$.
} 
regulation should only happen at the national level or be imposed by the EU. The EU Commission and the EU Parliament apparently act on the assumption that EU competence on the subject exists. This is supported by the argument that divergent national quota laws can be obstacles for businesses in the EU internal market. ${ }^{105}$ Concerns have been expressed at the national level, though. Criticism focuses on the principle of subsidiarity ${ }^{106}$ that might be violated by EU legislation. ${ }^{107}$ This fear, among others, has even been expressed by the German Ministry of Family Affairs, Senior Citizens, Women and Youth. ${ }^{108}$ It is questionable whether a sufficient basis for EU competence exists. This has seldom been discussed in the professional literature. However, a very thorough examination by a German professor has recently answered the question in the negative. ${ }^{109}$ Another objection to the EU's line of action has targeted Commissioner Reding's heavy reliance on the finding that three-quarters of Europeans are in support of quota legislation. This, it is argued, effectively comes very close to law-making by referendum which would not be allowed under EU rules. ${ }^{110}$ In conclusion, one can predict that EU efforts to adopt quota laws would be exposed to fierce criticism from some member states.

\section{E Summary and Analysis}

At both a national and EU level, there have been serious attempts to address board diversity, in particular, the issue of underrepresentation of women on the boards of public companies. The European countries Belgium, Norway, France, the Netherlands and Spain have taken the lead in introducing legislation to mandate up to $40 \%$ women on the boards of public companies. Understandably, especially because there are severe sanctions such as the possibility of deregistration linked to not achieving the quotas, considerable increases in the number of females on boards of public companies have been achieved in those countries. There are, however, several other countries where it is argued that the same could be achieved, over time, through voluntary codes of conduct. It is therefore clear that there is currently a deep divide as to what method should be used to achieve board diversity generally, and gender diversity in particular. However, there is little doubt that it is generally accepted that the issue of general imbalance in favour of men should be addressed. Opinions also vary as

\footnotetext{
${ }^{105}$ EC Press Release IP/12/213, above n 23, 2.

${ }^{106}$ Treaty on European Union, above n 69, art 5 ( $3^{\text {rd }}$ para).

${ }^{107}$ François-Poncet et al, above n 16, 454; Bachmann, above n 92, 1135.

${ }^{108}$ As quoted in 'Deutschland wehrt sich gegen EU-weite Frauenquote', Welt (Online), 5 March $2012<$ http://www.welt.de/dieweltbewegen/article13904721/Deutschland-wehrt-sich-gegen-EUweite-Frauenquote.html, 5 March 2012>.

109 Jens Koch, 'EU-Kompetenz für eine Frauenquote in den Führungsgremien von Aktiengesellschaften' (2011) 175 ZHR 827.

${ }^{110}$ Quoted in Welt (online), above $\mathrm{n} 108$.
} 
to what the ideal balance is or what the quota should be. Our research reveals that it is highly likely that the topic of board diversity and gender diversity in particular will remain a 'hot topic' in Europe, both at national and EU levels.

There are some very interesting challenges ahead for the EU. There are possible constitutional objections that could be raised against mandatory gender quota legislation but there are at the same time constitutional protections that could be used to justify mandatory gender quota legislation. For instance, both national constitutions and EU law demand, in one or other form, equality of men and women as a guiding principle and as a fundamental right. This fact is stressed by supporters of quota legislation who can also invoke, for their purposes, EU and national rules that allow for the adoption of measures providing for specific advantages in favour of the underrepresented sex, to compensate, eg, for disadvantages in professional careers. In principle, this will also apply to underrepresentation of women on boards.

\section{Australia}

\section{A Overview}

The fact that in most Australian company boards there is a gender imbalance in favour of men has never been disputed. All data available show the gender imbalance (in favour of men) very clearly, and that the gender balance is still not right is obvious - see data below. However, especially since 2010, there have been serious efforts to make sure that more women are appointed to Australian boards, especially for listed public companies. The gender imbalance on boards is currently being addressed by the Australian Securities Exchange's (ASX) Corporate Governance Principles and Recommendations, ${ }^{111}$ which is the voluntary code of corporate governance applying to all listed companies through the ASX's Listing Rules. It is not difficult to predict that if the right gender balance is not going to be achieved through this voluntary code of corporate governance, as in some other countries (see discussion below), mandatory quotas of women on Australian boards will be dictated by legislation.

\footnotetext{
111 ASX Corporate Governance Council, Corporate Governance Principles and Recommendations with $2010 \quad$ Amendments $\quad\left(2^{\text {nd }}\right.$ ed, 2010$)$ $<$ http://www.asxgroup.com.au/media/PDFs/cg_principles_recommendations_with_2010_amend ments.pdf $>$.
} 
B ASX Corporate Governance Council: 2010 Amendments to the 2007 Corporate Governance Principles and Recommendations

\section{Overview}

In 2010 several amendments were made to the ASX's Corporate Governance Principles and Recommendations. These amendments were also informed by the 2009 Report on Diversity on Boards prepared by the Australian Government's Corporations and Markets Advisory Committee (CAMAC). ${ }^{112}$ Several of these changes deal with board diversity. Recommendation 3.2 currently reads as follows:

Companies should establish a policy concerning diversity and disclose the policy or a summary of that policy. The policy should include requirements for the board to establish measurable objectives for achieving gender diversity for the board to assess annually both the objectives and progress in achieving them.

The ASX Corporate Governance Council suggested that a diversity policy should be established in the financial year commencing 1 July 2010. As far as the ASX Corporate Governance Principles and Recommendations are concerned, it was made clear that diversity includes, but is not limited to, gender, age, ethnicity and cultural background. The measurable objectives should identify ways in which the achievement of gender diversity is measured, for example, the proportion of women employed by (or who are consultants to) the company in senior executive positions and on the board. Where companies establish a diversity policy, they should also introduce appropriate procedures to ensure that the policy is implemented properly, which may include additional measurable objectives in relation to other aspects of diversity as identified in the policy. There should also be an internal review mechanism to assess the effectiveness of the policy.

Box 3.2 of the ASX Principles and Recommendations contains some suggestions for the content of a diversity policy. It is clear that the suggestions are not only aimed at gender diversity at board level, but diversity generally at all levels. It is suggested that companies should articulate their commitment to diversity, the corporate benefits arising from employee and board diversity, and the importance of benefiting from all available talent. It is suggested this would promote an environment conducive to the appointment of well-qualified

\footnotetext{
112 CAMAC, Diversity on Boards (March 2009) Australian Government $<$ http://www.camac.gov.au/camac/camac.nsf/byHeadline/PDFFinal+Reports+2009/\$file/Board_ Diversity_B5.pdf $>$.
} 
employees, senior management and board candidates so that there is appropriate diversity to maximise the achievement of corporate goals.

The fact that the focus is not on gender diversity only, is also confirmed by the suggestion in the ASX Principles and Recommendations that there should be a commitment to, and identification of, ways to promote a corporate culture which embraces diversity when determining the composition of employees, senior management and the board, including recruitment of employees and directors from a diverse pool of qualified candidates. Skills development, such as executive mentoring programs or more targeted practices relating to career advancement such as those that develop skills and experience that prepare employees for senior management and board positions, will also enhance the skills diversity of ordinary employees, managers, senior executives and board members. ${ }^{113}$

\section{Gender Diversity}

Recommendation 3.4 deals specifically with gender diversity:

Companies should disclose in each annual report the proportion of women employees in the whole organisation, women in senior executive positions and women on the board.

It is explained that diversity is an economic driver of competitiveness for companies. It is also pointed out that research has shown that increased gender diversity on boards is associated with better financial performance, and that improved workforce participation at all levels positively influences the economy. ${ }^{114}$ Kang, Cheng and Gray point out that there has been mixed evidence and constant debate regarding the effect of board composition on corporate performance. ${ }^{115}$ However, they find that board diversity is still considered to be desirable, because it results in more balanced board discussions. $^{116}$

The ASX Principles and Recommendations suggest that the promotion of gender diversity broadens the pool for recruitment of high-quality employees, enhances employee retention, encourages greater innovation, and improves corporate image and reputation. Reporting on the diversity profile of the

\footnotetext{
${ }^{113}$ ASX Corporate Governance Council, above n 111, Box 3.2.

${ }^{114}$ Ibid, Commentary on Recommendation 3.4, 25.

115 Helen Kang, Mandy Cheng and Sidney J Gray, 'Corporate Governance and Board Composition: Diversity and Independence of Australian Boards' (2007) 15 Corporate Governance: An International Review 194, 194.

${ }^{116}$ Ibid 194-5.
} 
company facilitates greater transparency and accountability in relation to the policy that has been put in place, together with the objectives to be achieved by the company. Companies should consider, in the context of the economic group controlled by the company, how best to report to achieve an accurate and nonmisleading impression of the relative participation of women and men in the workplace and the roles in which they are employed. For instance, this might be whether a full-time equivalent measure is appropriate in all or some circumstances as opposed to clear categorisation of full-time, part-time and contracted services, and whether the participation is in a leadership, management, professional specialty or supporting role, or by relative participation of men and women at different remuneration bands. The board, or an appropriate board committee, such as the nomination or remuneration committee, should be charged with the duty, at least annually, to review and report on the relative proportion of women and men in the workforce at all levels of the economic group controlled by the company. This obligation should be included in the charter of the board or the relevant board committee. ${ }^{117}$

Recommendation 3.5 covers reporting on diversity 'comply or explain' provisions - the reporting should be included in the corporate governance statement in the annual report. It is then provided that the following material should be made publicly available, ideally by posting it to the company's website in a clearly marked corporate governance section:

- $\quad$ any applicable code of conduct or a summary; and

- $\quad$ the diversity policy or a summary of its main provisions.

In recent time several initiatives have been undertaken in Australia to increase the skills base of women and to ensure that more women are appointed to boards. The changes to the ASX's Principles and Recommendations above clearly have this aim in mind. In April 2010 the Sex Discrimination Commissioner of the Australian Human Rights Commission, Elizabeth Broderick, ${ }^{118}$ brought together a group of influential business leaders, which led to the formation of a 'Male Champions of Change Group'. This group actively promotes the appointment of more women in leadership positions and also advises the Commissioner on gender issues. ${ }^{119}$ In 2010 the Business Council of Australia (BCA) established a one-year pilot mentoring program for highachieving women within the BCA member companies, called the ' $\mathrm{C}$ Suite'

\footnotetext{
${ }^{117}$ ASX Corporate Governance Council, above n 111, Commentary on Recommendation 3.4, 25.

118 See Human Rights Commission, Elizabeth Broderick $<$ http://humanrights.gov.au/about/president_commissioners/broderick.html>.

119 See Human Rights Commission, Male Champions of Change $<$ http://humanrights.gov.au/sex_discrimination/male-champions/index.html>.
} 
Project. The project involved BCA members in personally mentoring women employed by other BCA member companies. This kind of one-on-one mentoring by people at the top aims to open up pathways for talented women to rise up the corporate ladder. ${ }^{120}$ A similar initiative called the Mentoring Program was undertaken by the AICD. It was first launched in April 2010. The Program involves leading chairmen and directors working with highly talented and qualified women in a 12-month mentoring relationship. It is a practical and concrete measure designed to help achieve a greater representation of women on boards. ${ }^{121}$ Other initiatives of the AICD include the Board Ready Program, Board Diversity Scholarship Program and several places reserved for women on the AICD's Company Directors Course, which they may attend without paying the course fee of $\$ A U 5,400$ for those who are members of the AICD. ${ }^{122}$

Real-time statistics collated by the AICD in October 2010 show that: ${ }^{123}$

- women then represented $10.1 \%$ of directors of ASX200 boards, up from 8.3\% at the beginning of 2010 and higher than the $8.4 \%$ figure stated in the Equal Opportunity for Women in the Workplace Agency (EOWA) Census;

- a total of 40 women directors have been appointed up to October 2010, compared to only 10 for the whole of 2009;

- $27 \%$ of directors appointed up to October 2010 have been female, compared to only 5\% in 2009 and 8\% in 2007 and 2008;

- there were then six female chairs (one more than noted by EOWA) and seven female CEOs (one more than noted by EOWA);

- 37 companies then had two or more women on their boards (11 more than noted by EOWA);

- the proportion of companies with no women on their boards has fallen from $54 \%$ as recorded in the 2010 EOWA Census to $46.5 \%$; and

120 See BCA, A Role for Business - Women in the Leadership Suite (2012) $<$ http://www.bca.com.au/Content/101727.aspx>.

121 See AICD, Chairman's Mentoring Program (2011) $<$ http://www.companydirectors.com.au/Director-Resource-Centre/Governance-and-DirectorIssues/Board-Diversity/Mentoring-Programs>.

${ }^{122}$ See AICD, Board Diversity (2011) <http://www.companydirectors.com.au/Director-ResourceCentre/Governance-and-Director-Issues/Board-Diversity>.

${ }^{123}$ AICD, 'More Action Needed but Progress being Made on Women Directors' (Media Release, 6 October 2010) <http://www.companydirectors.com.au/General/Header/Media/MediaReleases/2010/More-action-needed-but-progress-being-made-on-women-directors>. 
- a total of 93 boards still did not have any women directors (15 less than noted by EOWA) by October 2010.

Up to May 2011, 79 boards in the ASX200 companies still had no women, but this was a significant improvement as, in the beginning of 2010, there were 115 ASX200 companies without any women on their boards. ${ }^{124}$ In August 2011 the following statistics were provided by the AICD: ${ }^{125}$

- women made up $17.6 \%$ of directors of ASX50 companies, $16.1 \%$ of ASX100 companies and $12.7 \%$ of ASX200 companies (it was said, at that stage, by the AICD chairman, John Colvin, that 'Australia now ranks ahead of many of our international peers in gender composition of top listed company boards, including the United Kingdom, Canada and New Zealand'; and

- up to August 2011, women comprised an average of $29 \%$ of all new appointments to ASX200 companies, compared to only 5\% in 2009 and $8 \%$ in 2007 and 2008.

On 23 August 2012 the AICD provided the following statistics: ${ }^{126}$

- women made up $14.5 \%$ of board members for ASX200 companies;

- it was reported that 56 ASX200 boards still do not have any women; and

- in line with 2011 figures, up to August 2012, 28\% of all 2012 board appointments for ASX200 companies were women.

The AICD points out that in August 2012 the number of women on the boards of ASX200 companies is the highest ever, but admits that there is still a long way to go ${ }^{127}$ as is also illustrated by Forbes' 2012 Index, placing Australia in the $21^{\text {st }}$ position out of 50 as far as the percentage of women on boards in Australia

\footnotetext{
124 AICD, 'Directors Continue to Lead in the Push to Increase Women on Boards' (Media Release, 2 May 2011). For 2006 data, see Kang et al, above n 115, 199-200.

125 AICD, 'Diversity Drives Corporate Performance' (Media Release, 9 August 2011) $<$ http://www.companydirectors.com.au/General/Header/Media/Media-Releases/2011/Diversitydrives-corporate-performance $>$. For slightly more updated statistics, see Deloitte, above n 11, 6 . In November 2011, it was $12.5 \%$.

126 See AICD, <http://www.companydirectors.com.au/Director-Resource-Centre/Governanceand-Director-Issues/Board-Diversity/Statistics>. See also 'Governance of Listed Companies' (2012) 28 (October) Company Director 60, 61.

${ }^{127}$ See AICD, above n 126.
} 
is concerned. ${ }^{128}$ This is the case irrespective of the fact that Australia ranks reasonably well as far as employee diversity generally is concerned and is in fact ranked fourth out of 50 nations. ${ }^{129}$ It is easy to predict that more women will be appointed on Australian boards in the future. Gender diversity is nowadays driven by the reporting requirements on the number of women employees and directors and there is also investor as well as community pressure that more women should be appointed on Australian boards. In addition, there are serious attempts from the the Sex Discrimination Commissioner Elizabeth Broderick to ensure that appropriate female targets for board appointments are achieved. Specific legislation in Australia, like the Workplace Gender Equality Act 2012 (Cth), ${ }^{130}$ requires reporting on the number of males and females employed and will ensure equality in this regard over time. Ensuring equality at lower levels of appointment will eventually lead to more women being appointed in middle, senior and executive positions, which will naturally also have a flow-on effect to the appointment of more women on boards. The Australian Human Rights Commission's 2010 Gender Equality Blueprint has made a recommendation that a target of $40 \%$ females on all listed companies should be promoted by $2015^{131}$ and Ms Broderick is actively promoting the achievement of this target. It will be clear that this target is based on the Norwegian example (as targets only at this stage), but it is also not difficult to predict that if targets are not set and/or targets are not achieved by companies, quota legislation may well be the next step also in Australia to ensure that a significant number of females are appointed to at least the boards of Australian listed companies. ${ }^{132}$

It is easy to predict that more women will be appointed on Australian boards in the future. On the one hand, this is driven by the reporting requirements on the number of women employees and directors; on the other hand, there is investor pressure that more women should be appointed to boards.

\footnotetext{
${ }^{128}$ Forbes Insights 2012, Diversity \& Inclusion: Unlocking Global Potential: Global Diversity $\begin{array}{lllll}\text { Rankings by Country, Sector and } & \end{array}$ $<$ http://images.forbes.com/forbesinsights/StudyPDFs/global_diversity_rankings_2012.pdf>.

${ }^{129}$ Ibid 3, 14.

${ }^{130}$ See <http://www.fahcsia.gov.au/sites/default/files/documents/05_2012/eowa_fact_sheet.pdf>.

131 Australian Human Rights Commission, 2010 Gender Equality Blueprint 16 $<$ http://www.humanrights.gov.au/sex_discrimination/publication/blueprint/Gender_Equality_Bl ueprint.pdf $>$.

132 See generally Douglas M Branson, 'An Australian Perspective on a Global Phenomenon: Initiatives to Place Women on Corporate Boards of Directors' (2012) 27 AJCL 2; Peta Spender, 'Gender Diversity on Board of Australia' (2012) 27 AJCL 22, 23, 25-8, 35-7; Susan Watson, 'Gender Diversity on Boards in New Zealand — Followers Not Leaders' (2012) 27 AJCL 39.
} 


\section{Summary and Analysis}

The debate on board diversity in Australia is dominated by gender diversity. However, it is clear that gender diversity is seen in the broader context of board diversity generally, including age, ethical and cultural diversity. In 2010 the ASX Corporate Governance Principles and Recommendations were amended to ensure that listed companies develop a diversity policy and that a summary of that policy should be disclosed. There should also be procedures in place to ensure compliance with the diversity policy. Box 3.2 of the Principles and Recommendations contains some specific suggestions on what issues should be dealt with in a diversity policy. As far as gender diversity is concerned, listed companies should disclose in each annual report the proportion of women employees in the whole organisation, women in senior executive positions and women on the board. This is an 'if not, why not?' provision, meaning that companies will have to explain if they do not disclose the information. Several initiatives by the BCA and the AICD are aimed at not only giving women exposure to senior executive function and board functions, but also providing women the opportunity to attend directors training courses.

The statistics show that there are still not many women serving on the boards of ASX200 companies. However, there are strong indications that this is changing rapidly.

\section{SOUth AfRICA ${ }^{133}$}

\section{A Overview}

A 2011 census, relying on data up to 30 September 2010, revealed that $15.8 \%$ of all South African directorships in listed public companies were held by women. The census report points out that, at that stage, the percentage of women on boards of listed South African companies was better than South Africa's international counterparts. ${ }^{134}$ In fact, other comparative data clearly shows that in comparison with Australia, Canada, New Zealand, the United Kingdom, the United States, China and Singapore, South Africa was in the lead as far as the percentage of female board positions and female executive manager positions

\footnotetext{
133 The authors thank Ansie Ramalho (BIuris, LLB), Chief Executive of the Institute of Directors in Southern Africa (IoDSA), for her assistance with the South African part of this article.

134 See, eg, Businesswomen's Association of South Africa, BWA South African Women in Leadership Census 2011 (2011)

<http://www.bwasa.co.za/Census/2011CensusResults/tabid/14840/Default.aspx>.
} 
for listed companies was concerned. Women held $16.6 \%$ of directorships and $19.3 \%$ of executive manager positions in listed South African companies. ${ }^{13}$

Business Unity South Africa (BUSA) undertook a study in transformation of board positions held on 269 companies listed on the Johannesburg Stock Exchange at March 2011, and provided the following data: ${ }^{136}$

\begin{tabular}{|l|c|c|}
\hline & Women & Black \\
\hline Directors & $14 \%$ & $25.3 \%$ \\
\hline Executive Directors & $7.4 \%$ & $9.5 \%$ \\
\hline $\begin{array}{l}\text { Non-Executive } \\
\text { Directors }\end{array}$ & $12.9 \%$ & $27.6 \%$ \\
\hline $\begin{array}{l}\text { Independent Non- } \\
\text { Executive Directors }\end{array}$ & $21.2 \%$ & $38.1 \%$ \\
\hline
\end{tabular}

BUSA points out that the Black Economic Empowerment Code 2007 (South Africa) (BEE Code) sets out to achieve 50\% black directors by $2017 .{ }^{137}$

The Businesswomen's Association of South Africa has undertaken a Women in Leadership Census since 2004. ${ }^{138}$ These reflect women in directorships, as follows, over the period:

- $\quad 2004: 7.1 \%$

- $2005: 10.7 \%$

- $2006: 11.5 \%$

- $2007: 13.1 \%$

- $2008: 14.3 \%{ }^{139}$

- $\quad 2009: 14.6 \%$

- $\quad 2010: 16.6 \%$

- $\quad 2011: 15.8 \%$

135 Jennifer Whelan and Robert Wood, 'Targets and Quotas for Women in Leadership: A Global Review of Policy, Practice, and Psychological Research' (Gender Equality Project, Centre for Ethical Leadership, Melbourne Business School, University of Melbourne, May 2012) 16.

${ }^{136}$ See BUSA, Business Unity South Africa (Busa) Transformation Study: A Snapshot of the Demographic Profile and Pace of Transformation of JSE Listed Companies <http://www.busa.org.za/docs/SUMMARY\%20A\%20Snapshot\%20of\%20the\%20Demographic \%20Profile\%20and\%20Pace\%20of\%20Transformation\%20of\%20JSE\%20listed\%20companies. $\operatorname{pdf}>$.

${ }^{137}$ See also <www.thedti.gov.za/economic_empowerment/bee_codes.jsp>.

${ }^{138}$ See Businesswomen's Association of South Africa, above n 134, 10.

${ }^{139}$ In 2008 39.6\% of Johannesburg Stock Exchange listed companies had no women and only $7.8 \%$ of all CEOs for listed companies were women - see Sharon Davis, 'Steady Progress towards Gender Equality in Corporate World' (2008) October-December WITS Business School Journal 23. 
The above statistics must be seen against the backdrop of a total population of 50.59 million, of which approximately $52 \%$ is female, according to estimated statistics for mid-2011. ${ }^{140}$ The annual report of the Commission of Employment Equity covering the period 2010-2011 shows that females constitute $44.8 \%$ of the total economically active population in South Africa. ${ }^{141}$

According to a paper by Mathur-Helm, reaching top-level positions is still uncommon for South Africa's women, as its corporate environment is not yet ready to accept women as professional equals. She found that government legislation and policies work against women's growth and advancement rather than in their favour, because they are dependent on management strategies that treat women differently in terms of social constructs, attitudes and norms and stereotypes created by corporate culture in South Africa. ${ }^{142}$

In comparison it is, however, positive to note the steady increase of females and black persons in membership of the Institute of Directors in Southern Africa (IoDSA) over the past five years. Whilst not all members are directors of companies, such members do meet the strict membership criteria of IoDSA and hold significantly senior positions in business, para-statals or a profession.

The steady increase in membership of women and black persons in the IoDSA is clearly illustrated by the following table:

\begin{tabular}{|c|c|c|}
\hline & Women & Black \\
\hline 2007 & $19 \%$ & $35 \%$ \\
\hline 2008 & $21 \%$ & $37 \%$ \\
\hline 2009 & $23 \%$ & $40 \%$ \\
\hline 2010 & $24 \%$ & $42 \%$ \\
\hline 2011 & $26 \%$ & $45 \%$ \\
\hline
\end{tabular}

It is worth mentioning that in 2011 the IoDSA had approximately 5,000 members. The IoDSA has successfully, together with various of its key stakeholders, focused on marketing and other appropriate initiatives to try to ensure the required growth is achieved, and is still striving to get more women and black persons as members. This will, over time, ensure that the pool of

\footnotetext{
140 See Statistics South Africa, Mid-Year Population Statistics 2011 (2011) $<$ http://www.statssa.gov.za/publications/P0302/P03022011.pdf>.

${ }^{141}$ See Department of Labour, Republic of South Africa, $11^{\text {th }}$ CEE Annual Report 2010-2011 $<$ http://www.info.gov.za/view/DownloadFileAction?id=148340>.

${ }^{142}$ Babita Mathur-Helm, 'Equal Opportunity and Affirmative Action for South African Women: A Benefit or Barrier?’ (2005) 20 Women in Management Review 56.
} 
qualified women and black persons to fill board positions will be even bigger which will assist in achieving and ensuring a better diversity on the boards of South African companies as far as gender and race are concerned.

\section{B Corporate Governance Influence}

It should be noted that board composition and diversity in South Africa need to be viewed in the context of a unitary board structure, with minimal stakeholder participation other than appointment of representative directors by major shareholders in certain instances. ${ }^{143}$ Also, the business environment in South Africa operates within the context of a post-apartheid regime. In the Bill of Rights contained in the Constitution of the Republic of South Africa Act 1996 (South Africa) it is provided that discrimination on the grounds of, inter alia, race and gender is unlawful, which assists, to a certain extent, to achieve diversity on boards.

Whilst South Africa's population is extremely diverse, board diversity in particular has been driven, encouraged, and supported in the post-apartheid era, not only by business and individuals, but also by various codes, charters, quotas and legislation. ${ }^{144} \mathrm{~A}$ particularly interesting aspect in South Africa is that companies may choose to be measured using the Generic Scorecard or their individual sector scorecards. The Generic Scorecard requires companies to report on seven Broad-Based Black Economic Empowerment (B-BBEE) pillars, each of which contributes to the outcome of the scorecard. The B-BBEE Generic Scorecard emphasises all aspects of business and society. Each pillar is worth between five and 20 points on the scorecard. Companies with annual turnover above R35 million per annum must comply with all seven pillars of the Generic Scorecard. One of the main objectives for the government in bringing out a generic scorecard was to promote economic transformation in order to enable meaningful participation of black people in the South African economy. ${ }^{145}$ Various sector scorecards have already been developed, including construction, tourism, forestry, transport, finance, ICT, mining, and

\footnotetext{
${ }^{143}$ See s 66(1) of the Companies Act 2008 (South Africa) for the powers and functions of the board and the appointment and election of directors.

144 See Broad-Based Black Economic Empowerment Act 2003 (South Africa) (Codes of Good Practice on Black Economic Empowerment in South Africa, South African Government Gazette, No 29617, 9 February 2007).

${ }^{145}$ See Permier Verification - B-BBEE Verification Services, The Generic Scorecard (26 May 2010) <http://www.premierbee.co.za/downloads/Generic_scorecard.pdf> .
} 
petroleum. ${ }^{146}$ It is clear that these scorecards focus the attention on BEE and also directly on board diversity.

In 1993 the King Committee was formed, named after its Chair, former Supreme Court judge, Mervyn King. ${ }^{147}$ The Reports by this committee became known as King I (1994), ${ }^{148}$ King II (2002) ${ }^{149}$ and King III (2010). ${ }^{150}$ In King I and II there was no specific focus on board diversity in the context of gender and race, but board diversity as far as a balance of executive and non-executive directors is concerned was a prominent focus in both reports. ${ }^{151}$ The impact of the King Reports was considerable with some unique and innovative approaches to corporate governance, which have since been adopted and have influenced strategic thinking on corporate governance in many parts of the world. ${ }^{152}$ The landscape shifted somewhat with the advent of King III, which acknowledged that social transformation and redress from apartheid was important, and should be integrated within the broader transition to sustainability in a strategic and coherent manner, to give rise to greater opportunities, efficiencies and benefits for both companies and society. ${ }^{153}$ The benefit of involving women, particularly in sustainability issues, is an added dimension in terms of increased diversity of thinking and bringing a powerful consumerism aspect to the fore. ${ }^{154}$

King III continued to suggest that strategies and policies designed to achieve responsible corporate citizenship should be planned and co-ordinated across all sections of a company to avoid fragmentation. ${ }^{155}$ By way of an example, a scenario where a company seeks to respond to the requirements of an industryspecific BEE Charter, ${ }^{156}$ as well as the government's B-BBEE Scorecard, ${ }^{157}$ but

146 See for the Construction Sector Scorecard, Basil Read, Sustainable Development (2009) $<$ http://financialresults.co.za/2010/basilread_ar2009/sd_scorecard.htm>. For the Tourism Sector Scorecard, see Avis, Rent A Car Report <www.avis.co.za/AboutAvis/AvisBBBEE.aspx>.

${ }^{147}$ See generally Mervyn E King SC (2012) <http://www.mervynking.co.za/>.

${ }^{148}$ The King Report on Corporate Governance (King I) (Institute of Directors in Southern Africa, 1994).

${ }^{149}$ King Report on Corporate Governance for South Africa - 2002 (King II) (Institute of Directors in Southern Africa, 2002).

${ }^{150}$ King Report on Governance for South Africa - 2009 (King III) (Institute of Directors in Southern Africa 2009) <http://african.ipapercms.dk/IOD/KINGIII/kingiiireport/>.

${ }^{151}$ King I, above n 148, 12 [16]-[17]; 'Recommendations' in King II, above n 149, 60; see also 57-8 [7]-[10].

152 Jean J du Plessis, J Anil Hargovan and Mirko Bagaric, Principles of Contemporary Corporate Governance (Cambridge University Press, 2011) 8, 11-12, 51-2, 96.

${ }^{153}$ See King III, above n 150, 14.

${ }^{154}$ See our discussion below: '3 Reasons for having more women on boards'.

${ }^{155}$ King III, above n 150, 24 [29].

156 See, eg, Old Mutual, Black Economic Empowerment Charter (2012) $<$ http://www.oldmutual.co.za/about-us/transformation/black-empowerment/old-mutual\%27sbee-charter.aspx> . 
fails to integrate these efforts effectively into a broader sustainability framework results in fragmentation and needs to be avoided. A 'tick box' approach to governance and compliance is therefore discouraged by King III, and a shortsighted approach to governance is viewed as contributing to inefficiencies which result in investments with poor social returns, as well as corporate failures. ${ }^{158}$

King III went on to assert that the connection between sustainability and BEE is not always fully understood, and that consequently there is a significant opportunity to clarify and institutionalise it to leverage on investors' growing recognition of sustainability when considering an investment. It was also felt that using this opportunity would engender greater confidence in considering South Africa as an investment destination. ${ }^{159}$

King III also supports the positive interaction between the diversity of views that occurs between individuals of different skills, experience and backgrounds, and considers a unitary board structure, with executive directors and nonexecutive directors interacting in working groups, as appropriate for South African companies. King III specifically recommends that every board should consider whether its size, diversity and demographics make it effective, with diversity being considered in relation to academic qualifications, technical expertise, relevant industry knowledge, experience, nationality, age, race and gender. ${ }^{160}$

The importance of board diversity is highlighted in King III by focusing on the positive interaction and diversity of views that occur in boards made up of individuals with different skills, experience and background. ${ }^{161}$ The important role of independent non-executive directors in a unitary board structure is also emphasised as they bring objective judgment on all issues facing the company, including strategy, performance, sustainability, resources, transformation, diversity, employment equity, standards of conduct and evaluation of performance. ${ }^{162}$ The recruitment of such non-executive directors from a broader and more diverse pool would serve to enhance the breadth and depth of input on the required deliberations, considerations and decisions to be taken.

\footnotetext{
${ }^{157}$ See Basil Read, above n 146; Avis, above n 146.

${ }^{158}$ King III, above n 150, 24 [31].

${ }^{159}$ Ibid 24 [32].

${ }^{160}$ Ibid 38 [62], 39 [71].

${ }^{161}$ Ibid 38 [62].

${ }^{162}$ Ibid ch 2 [71].
} 
In October 2010, the King Committee issued a Practice Note on B-BBEE, ${ }^{163}$ which highlighted that the empowerment of previously disadvantaged individuals, in particular black women, workers and people with disabilities (collectively referred to as 'black people'), should be based on the premise of equal partnership in the corporate sphere, with their contributions being equally valuable. The Practice Note further recommends that in addition to a company disclosing its B-BBEE rating in its annual report, disclosure of 'the significance of the roles played by black people on the Board, Remuneration Committee, Nominations Committee and other important Committees' is useful to stakeholders.

To this end it is concluded in the Practice Note that all businesses in South Africa acknowledge that successfully implementing B-BBEE is not only ethically right, but also commercially prudent, and a necessary measure for the normalisation of South African society, and specifically the socio-economic uplifting of black people. It is important to consider this aspect and balance it against a possible investor's view either in South Africa or from an external investor's point of view. South Africa is still a very good investment option for foreign investors. ${ }^{164}$ The attractiveness of South Africa for investors will, over the long run, depend on the operating efficiencies of companies and a healthy diversity on boards where a merit-based approach for board appointments forms part of the corporate culture of companies. ${ }^{165}$ It is evident that huge importance is placed on ensuring the correct level of diversity in terms of the demographics on a board, in the socio, political and economic context of the community, and the environment in which the company operates in South Africa.

In all three King Reports a legislative and principle-based approach to corporate governance was duly considered. King III was explicit in adopting an approach to align the voluntary code of good corporate governance with new company law legislation. ${ }^{166}$ In King III an 'apply or explain' approach was adopted which was considered to allow sufficient flexibility to cater for the specific needs of a business entity, and ensure adequate focus by the board and management on these matters. ${ }^{167}$

\footnotetext{
163 See $\quad$ Iodsa, $\quad$ King III $\quad$ Practice $\quad$ Notes

<http://www.iodsa.co.za/PRODUCTSSERVICES/KingIIIReportPapersGuidelines/KingReporto nCorporateGovernanceinSA/KingIIIPracticeNotes.aspx>.

${ }^{164}$ See Mariam Isa, 'SA Tops Subregion in Foreign Direct Investment', BusinessDay (online), 6 July 2012 <http://www.businessday.co.za/articles/Content.aspx?id=175726>.

165 On the 'merit principle' as a reason not to have targets or quotas for women, see Whelan and Wood, above $\mathrm{n} 135,9$.

${ }^{166}$ King III, above n 150, 5.

${ }^{167}$ Ibid 6.
} 


\section{Legislative Influence}

The South African government introduced various policy, legislative and regulatory interventions to specifically address the inequities of the past. The Employment Equity Act 1998 (South Africa) had as its main objective the promotion of equal opportunities and fair treatment in employment practices. Its purpose is also to proactively redress past disadvantages by providing a framework for affirmative action. The envisaged outcome is that there will be equitable representation of previously disadvantaged individuals in all occupation categories and levels in the workforce. ${ }^{168}$

The Skills Development Act 1998 (South Africa) was introduced to improve the employment prospects of persons previously disadvantaged by unfair discrimination, and to redress those disadvantages through training and education.

The National Policy Framework for Women's Empowerment and Gender Equality 1996 was issued by the Office on the Status of Women in the Presidency which has jurisdiction over the national gender. This Framework outlines South Africa's vision for gender equality and how it intends to reach that ideal. There is reference in the document to various white papers issue by government, including the White Paper on Transforming Public Service Delivery (1997) and the White Paper on Affirmative Action in the Public Service (1998). ${ }^{169}$

The Commission for Gender Equality is an entity created by the South African Constitution to address transformation in gender relations. Its mission is to advance, promote and protect gender equality in South Africa through undertaking research, public education, policy development, legislative initiatives, effective monitoring and litigation. ${ }^{170}$

The new Companies Act 2008 (South Africa) (the Act) is not prescriptive regarding diversity on boards, the rationale being that, generally, legislation should not impose but rather should facilitate this important consideration. The prescribed statutory requirements for directors to act in the best interests of the company as a whole and to recognise stakeholders' interests in an inclusive and integrated manner, serve to promote the skills and diversity attributes required of a board.

\footnotetext{
168 See Department of Labour, Republic of South Africa, Employment Equity Act (4 July 2012) $<$ http://www.labour.gov.za/legislation/acts/employment-equity/employment-equity-act>.

169 See The Office on the Status of Women, South Africa's National Policy Framework for Women's Empowerment and Gender Equality, South African Government $<$ http://www.info.gov.za/otherdocs/2000/gender.pdf >.

${ }^{170}$ See Commission for Gender Equality, 'Welcome’ (2012) <http://www.cge.org.za>.
} 
To ensure stakeholders' interests are protected and considered, the Act and attendant regulations require members of an audit committee to be directors of the company and to have suitable and relevant knowledge and experience to equip the committee to suitably perform its duties. ${ }^{171}$ The legislative move towards independence is, in itself, also a move towards diversity. The notion behind independence is that other views, as part of those of the executive directors, are also expressed in the boardroom.

The Act also requires certain categories of companies to constitute a Social and Ethics Committee. The committee's duties are prescribed, and include ensuring that a company gives due regard to the Employment Equity Act and the B-BBEE $A c t$, as well as social and environmental issues, and the integration thereof into strategic and economic performance. ${ }^{172}$ It can be argued that legislating the Social and Ethics Committee, and especially the regulation of its composition, is an attempt by the legislator to add diversity to the discussions around ethics, compliance, fraud prevention, and corporate citizenship in order that a broader view is taken into account by the board as a collective on these issues.

\section{Summary and Analysis}

Notwithstanding the progress that has been made on both gender and race diversity on company boards in South Africa, particularly in recent years, further progress is required, and is hindered by skills shortages and limited resource pools from which to draw directors with the requisite skills, qualifications and knowledge. The over-utilisation of a relatively small pool of skilled directors can lead to the inability of such directors to satisfactorily discharge and fulfill their duties in terms of their availability and time commitment. This aspect may be more challenging than in many other countries due to the particular political circumstances and dynamics of South Africa's past, as outlined above. Education and appropriate training for directors, including more foundation levels, have become increasingly more important in order to assist and drive the required changes. The IoDSA continues to play a critically important role in South Africa in this regard. ${ }^{173}$ It is suggested that, given the onerous responsibilities of directors and the potential legal liabilities (which have recently increased), careful consideration needs to be given to ensure that a person of whatever gender and/or race has sufficient skills and the ability to meet the legislative requirements and standards of duty.

\footnotetext{
${ }^{171}$ Companies Act 2008 (South Africa) s 94(4).

${ }^{172}$ Ibid s 72(4).

${ }^{173}$ See the Institute of Directors Southern Africa (2011) <http://www.iodsa.co.za>.
} 


\section{Broader Context}

In the previous sections we have focused on board diversity, including gender diversity, in Europe, Australia and South Africa or, in other words, in the context of specific countries or jurisdictions from different parts of the world. In the next two sections we focus on gender diversity in particular, but address some of the broader issues, principles and practical considerations. We also look at the mandatory gender quota debate in a broader context not linked to specific countries or jurisdictions.

\section{A The Gender Diversity Debate in Particular}

\section{Underrepresentation of Women on Boards is a Fact}

The debate on board diversity is dominated by gender diversity. There is ample evidence all over the world that, in the past, women were to a much greater extent, totally under-represented on boards, and there is not a single country in the world where this is still not the case. ${ }^{174}$ In countries like Norway, Spain, Switzerland, France, Israel and the Netherlands, where mandatory quotas are required through legislation, this has changed in recent times and will surely lead to further improvements in the gender balance on boards. ${ }^{175}$ However, as far as we know, there is not a single country in the world where women form more than $50 \%$ of the boards of listed companies. ${ }^{176}$ In most countries, especially western countries, where there are no mandatory quotas required, there have been serious attempts made through voluntary codes of good governance to improve female representation on company boards. It was shown above that in Australia, in several European companies and in South Africa, the process of appointing more women as employees, executives and directors is taken seriously. Also, there is considerable investor pressure on companies to

\footnotetext{
174 See Deloitte, above n 11; and Whelan and Wood, above n 135, 5-6. See generally, Boris Groysberg, 2011 Board of Directors Survey, Deloitte (2011) 3-4 $<$ http://www.corpgov.deloitte.com/binary/com.epicentric.contentmanagement.servlet.ContentDe liveryServlet/USEng/Documents/Nominating-

Corporate\%20Governance\%20Committee/Board\%20Composition\%20and\%20Recruitment/201 1BoardSurvey_HeidrickStrugglesWCDGroysberg_101111.pdf>.

${ }^{175}$ In Norway, which took the lead in 2005 to legislate for mandatory female quotas, it was shown that by the end of 2010, 31.9\% of the positions on the largest ASA company boards were filled by women, while $35.6 \%$ of such positions were filled by women in a sample of 25 listed companies researched by Deloitte - see Deloitte, above n 11, 21. Thus, although not at the required aspiration of $40 \%$ women on boards by 1 January 2008, the percentage is significantly higher than in any other country Deloitte included in their study.

${ }^{176}$ See comparative data provided by Whelan and Wood, above n 135, 17.
} 
get the gender balance right on boards. ${ }^{177}$ There is solid research showing that if a country stops short of adopting mandatory gender quotas, there should at least be very specific targets set by work units within companies, particularly at top executive levels, to achieve gender equality. ${ }^{178}$ Thus, it is to be expected that more women will definitely be appointed to company boards in future. As will be seen below, this trend has already started.

\section{Reasons for the Underrepresentation of Women on Boards}

The reasons for the low number of women serving on boards can be explained in different ways. The most basic explanation is that company boards have always been dominated by middle-aged men. As board appointments are normally made by invitation, 'the old boys' clubs' would always bring in their 'friends, mates and buddies' - trying to clone and, thus, perpetuate the evil! However, the matter is probably more complex than that. There are fewer women in senior managerial and senior executive positions, and even fewer women serving as CEOs. Thus, the argument is that the pool from which women board members is selected is simply smaller than the pool of men. The question then is why? Here, again, the simple argument is that underrepresentation of women at senior levels is explained by the fact that there has always been discrimination against women at these levels. In the past, women would hardly ever have been appointed to senior executive positions over men in a male-dominated environment.

The combined effect of these two practical realities has resulted in the assumption that there are simply not enough women to fill senior executive and board positions being challenged heavily. Those who argue against a significant increase of women on boards (especially by way of fixed legislative quotas) point out that there are frankly not enough qualified women to fill the board positions necessary to reach a threshold of $30 \%$ or $40 \% .{ }^{179}$ It is then argued that it would, in consequence, lead to the selection of women even in cases where better qualified male candidates have to be rejected. This is viewed as unacceptable under the assumption that quality should always be the most important criterion. ${ }^{180}$ The problem is worse in economic sectors where female employee rates have traditionally been low, as in the metal or electrical

\footnotetext{
177 Yi Wang and Bob Clift, 'Is there a "Business Case” for Board Diversity?' (2009) 21 Pacific Accounting Review 88, 89; Nicole Sandford, 'Board Diversity: Are We on the Eve of Real Change?’ (2011) 35 Directors \& Boards Annual 70.

${ }^{178}$ Whelan and Wood, above n 135, 5, 24-7.

${ }^{179}$ François-Poncet et al, above n 16, 454; Hirte, above n 32, 525.

${ }^{180}$ Daniela Weber-Rey, 'Gesetzliche Frauenquote?’ (2011) 44 ZRP 127; Krieger, above n 73, 918.
} 
industries, where the proportion of women employed might just reach $20 \%{ }^{181}$ This raises questions about the appropriateness of a 'one-size-fits-all' quota model. $^{182}$

However, the counter-argument is very strong, namely, that the number of talented females is sufficient but that there is a 'glass ceiling' barring them from getting to the top. ${ }^{183}$ Furthermore, the finding that in other similarly demanding fields of work (eg, politics, the judiciary) women have frequently reached top positions, is cited as proof that there are sufficient well-qualified women available. ${ }^{184}$ Membership on a supervisory board (where a two-tier system exists) is even seen as predestined to allow for the compatibility of work and family life because it does not amount to a full-time job. ${ }^{185}$ Another very interesting point of view, expressed as part of the discussion in Germany, is that it is not the quality of women that has to be improved, but rather the traditional prerequisites for supervisory board members should be reassessed. Recruitment for supervisory board positions should not primarily focus on former members of management boards (where, as was seen above, the percentages of women are very low), but rather focus on females from other professions, including scientists, lawyers, accountants, tax advisors etc. ${ }^{186}$

Another reason for the under-representation of women in senior management, senior executive and CEO positions could be that women traditionally have the primary responsibility for raising children, which may make the additional responsibility of taking up additional highly stressful managerial and executive positions less attractive to many women. In other words, it is a rational and practical career choice for women. ${ }^{187}$ However, as far as we know, there is no empirical data to support this claim, although it has been pointed out that many women in top management positions are married and have children, indicating that family and career aspirations can be successfully reconciled. ${ }^{188}$

All in all, it seems fair to conclude that almost all of the arguments mentioned in this section have some validity. This is true especially if one takes into consideration that there are other measures, apart from mandatory quotas, to

\footnotetext{
${ }^{181}$ Kempter, above n 76, 220.

${ }^{182}$ Weber-Rey, above n 180, 127; Krieger, above n 73, 918; Patrick Velte,'Förderung der Gender Diversity bei der Zusammensetzung des Aufsichtsrats’ (2012) 10 Der Konzern 7.

${ }^{183}$ FöGAbUG, BR-Drucksache 87/11, above n 49, 2; EC Press Release IP/12/213, above n 23, 2.

${ }^{184}$ Mayer, above n 46, 919; FöGAbUG, BR-Drucksache 87/11, above n 49, 15.

${ }^{185}$ Bachmann, above n 92, 1134.

${ }^{186}$ Mayer, above n 46, 919. See also Spender, above 132, 31-4; Bachmann, above n 92, 1134.

${ }^{187}$ Cf McKinsey \& Company, above n 67, 8: 'Companies need access to the biggest possible talent pool.'

${ }^{188}$ FöGAbUG, BR-Drucksache 87/11, above n 49, 14.
} 
increase female representation in top management, executive and board positions. As was seen in Australia and Germany, the various measures are starting to have an effect and increased percentages of women on boards can surely be expected in future.

\section{Reasons for Having More Women on Boards}

Time and space make it impossible to go into the numerous reasons in detail of why more women should be appointed to boards. The most simplistic reason is that it is 'the right thing to do', ${ }^{189}$ but there are many other good reasons that Whelan and Wood list to make out a case for greater gender diversity. ${ }^{190}$ It is hard to deny the notion that it constitutes a waste of potential to virtually ignore half of the population in the process of selecting company executives and board members. ${ }^{191}$ Also, adequate representation of both genders on boards is supposed to lead to a better management culture because, this way, male and female points of view and leadership styles are combined, thus making better use of the full range of available talents and, at the same time, meeting the needs of both men and women at work. ${ }^{192}$

Proponents of board diversity in general, and gender diversity specifically, point out that such variety brings with it economic advantages for the respective company. ${ }^{193}$ This is a key assumption by EU institutions as well as parties involved in the discussion at the national level. For example, the EU commission cites reports by McKinsey and Ernst \& Young that indicate significantly higher earnings by companies with female board members. ${ }^{194}$ Likewise, in its proposal for German legislation, the state of North RhineWestphalia refers to surveys that indicate that higher earnings come along with an increased number of women in top management positions. ${ }^{195}$

However, the 'business case' for gender diversity has never been proven convincingly. There is apparently 'evidence from the US that companies with more than three women on their boards performed significantly better than those

\footnotetext{
${ }^{189}$ See Diplock, 'Global perspectives' in Deloitte, above n 11, 2. See also Wang and Clift, above n 177, 89.

${ }^{190}$ Whelan and Wood, above n 135, 6; Spender, above 132, 37.

${ }^{191}$ See FöGAbUG, BR-Drucksache 87/11, above n 49, 16; Mayer, above n 46, 919. Also see EC Press Release IP/12/213, above n 23, 3; McKinsey \& Company, above n 67, 3.

${ }^{192}$ Whelan and Wood, above n 135, 3.

${ }^{193}$ See, eg, Mayer, above n 46.

${ }^{194}$ EC Press Release IP/12/213, above n 23, 1.

${ }^{195}$ See FöGAbUG, BR-Drucksache 87/11, above n 49, 16.
} 
that didn't', ${ }^{196}$ while a Research Report from Goldman Sachs suggests that achieving gender balance in the workforce could increase Australian gross domestic product by $11 \% .{ }^{197}$ It has also been pointed out that female board members may have a better understanding of consumer behaviour, the needs of customers, opportunities for companies to meet those needs and that they are more likely to be 'independent' as they would not come from the 'old boys' network' ${ }^{198}$ However, research on whether there definitely is a negative or positive relationship between the proportion of women on boards and company performance is still inconclusive. ${ }^{199}$ Wang and Clift refer to several studies on the link between the proportion of women on boards and the financial performance of companies, and conducted their own research based on data they collected and analysed. They conclude that 'there is no strong relationship between gender and racial diversity on the board and financial performance'. ${ }^{200}$ This is not totally unexpected as the criteria used for these studies differ and the circumstances and complexities of business are such that a final conclusion will probably never be reached. There are, however, some studies that show 'a correlation between the financial bottom line and the proportion of women on boards or in senior management'. ${ }^{201}$ However, the fact that the causal relationship between women's representation and corporate success has not been proven ${ }^{202}$ is generally acknowledged by those who cite the reports. ${ }^{203} \mathrm{In}$ fact, other explanations for the corporate success in these cases are possible, for example, boards with a higher percentage of women members often have a lower average age than comparable other boards where there is a higher number of males on the board. ${ }^{204}$

\footnotetext{
196 AICD, 'The Gender Imbalance', Company Director Magazine (1 June 2010) $<$ http://www.companydirectors.com.au/Director-Resource-Centre/Publications/Company-

Director-magazine/2010-back-editions/June-2010/June/Feature-The-gender-imbalance>.

197 Goldman Sachs, Australia's Hidden Resource: The Economic Case for Increasing Female Participation, Research Report (26 November 2009) 2 $<$ http://www.wgea.gov.au/pay_equity/pay_equity_information/australias_hidden_resource.pdf $>$.

${ }^{198}$ Kang et al, above n 115, 196.

${ }^{199}$ Wang and Clift, above n 177, 89-91; Renee Adams, 'Sorry, but there’s no Business Case for Gender Quotas' The Conversation (online), 29 August 2012 $<$ http://theconversation.edu.au/sorry-but-theres-no-business-case-for-gender-quotas-9145>.

${ }^{200}$ Ibid 97.

${ }^{201}$ Diplock, 'Global Perspectives’ in Deloitte, above n 11, 2.

202 This is pointed out by Kempter, above n 77, 220.

${ }^{203}$ See FöGAbUG, BR-Drucksache 87/11, above n 49, 16.

${ }^{204}$ For a more detailed analysis, see Hirte, above n 32, 521.
} 


\section{$4 \quad$ Gender Diversity on Boards Seen as Part of the Broader Debate on Board Diversity}

Over the last 15 years or so, the debate about female representation on boards has been seen in the context of the broader debate on board diversity, thus, approaching it from a more general corporate governance angle. Several recent surveys deal with diversity in general (not just gender diversity). ${ }^{205}$ It is now well recognised that there are advantages in having a board where there is diversity as far as race/ethnic background, ${ }^{206}$ nationality, gender, age, industry experience, and educational, functional and occupational backgrounds, are concerned. ${ }^{207}$

The advantages posited of a diverse board include promotion of a better understanding of the marketplace, increased creativity and innovation, effective problem-solving, enhanced effectiveness of corporate leadership, expanding global relationships, and avoidance of the dangers of 'group-think' in a homogeneous board. ${ }^{208}$ Diverse backgrounds and experiences are presumed to benefit the work of a governing body that has to deal with a multitude of different questions. ${ }^{209}$ However, what a board with a well-balanced composition is considered to be, and whether there is a 'business case' to be made out for board diversity, are complex issues with no clear answers, and diverging views based on a wide variety of different criteria to determine what is meant by 'diversity' and 'business success'. ${ }^{210}$

\footnotetext{
${ }^{205}$ Ibid.

${ }^{206}$ See generally Stephen Brammer, Andrew Millington and Stephen Pavelin, ‘Gender and Ethnic Diversity among UK Corporate Boards' (2007) 15 Corporate Governance: An International Review 393; Weber-Rey, above n 180, 127; and Kempter, above n 77, 220.

${ }^{207}$ Mayer, above n 46, 919; Velte, above n 182, 7.

${ }^{208}$ Wang and Clift, above n 177, 89; Kang et al, above n 115, 195; Brammer et al, above n 206, 394-6.

${ }^{209}$ For this reasoning, see EC Green Paper 2011, above n 35 [1.1.], [1.1.3]; FöGAbUG, BRDrucksache 87/11, above n 49, 17. See also McKinsey \& Company, above n 67, 3.

${ }^{210}$ See especially Wang and Clift, above n 177, 88. See also CAMAC, above n 112, 23ff; $\begin{array}{llllll}\text { Deloitte, } & 2011 & \text { Spencer } & \text { Stuart } & \text { Board } & \text { Index }\end{array}$ $<$ http://www.corpgov.deloitte.com/binary/com.epicentric.contentmanagement.servlet.ContentDe liveryServlet/USEng/Documents/Board\%20Governance/2011\%20US\%20Spencer\%20Stuart\%2 0Board\%20Index_Spencer\%20Stuart_110711.pdf>.
} 


\section{$5 \quad$ Research to be Undertaken over Time to Monitor Patterns} and Perceptions

It will provide for interesting research to compare current perceptions of directors along gender lines, that is: how male directors perceive other male directors; how female directors perceive other female directors; and then how the two groups perceive directors from the other sex. Also, it would be interesting to research the perception of two randomly selected groups of men and women who are non-managers, non-executives and non-directors to establish how they perceive male and female directors, respectively. It would then be interesting to monitor changes in perceptions over, say, a 10-year period. This idea was prompted by indications that male directors are still averse to promoting the idea of board diversity, and that it is probably linked to their perception that there should not necessarily be more females sitting on boards. Nicole Sandford provided this interesting example in 2011 of directors in America:

At a recent director education program hosted by a major university, the nearly 100 public company directors in attendance were polled on whether they believed diversity was an important consideration for board composition. The nearly all-male audience response was disheartening - approximately $70 \%$ said 'no'. A familiar conversation ensued: We want the best athlete and shouldn't be restricted by diversity: we believe diversity of thought is the most important factor. This view may have to change in the face of marketplace and investor pressures. ${ }^{211}$

Thus, if the research suggested above is undertaken, it is to be hoped that in 10 years' time there will not only be a roughly equal number of males and females attending a similar educational program, but that the advantages of board diversity will be acknowledged, and also that the male directors will acknowledge the invaluable contributions female directors make to boards. ${ }^{212}$

\section{B The Mandatory Gender Quota Argument in Particular}

\section{$1 \quad$ Positive Examples of Countries with Statutory Quotas}

The first argument in favour of quota legislation is obvious, that gender quota laws have achieved the desired results by increasing the percentage of women on boards. This fact is stressed by national political stakeholders ${ }^{213}$ as well as

\footnotetext{
${ }^{211}$ Sandford, above n 177.

${ }^{212}$ Interesting continuing research along gender lines is undertaken by women corporate directors — see the research sponsored by Hedrick \& Struggles, Groysberg, above n 174.

${ }^{213}$ See FöGAbUG, BR-Drucksache 87/11, above n 49, 15, 18.
} 
EU institutions. ${ }^{214}$ While the 'success stories' in countries like Norway and France can hardly be disputed, one still has to keep in mind a handful of other aspects. As mentioned, a positive trend had existed in France even before the creation of quota laws. It is impossible to determine what would have happened if the rules had not been passed. It seems fair to assume that the legal pressure contributed, at least somewhat, to the positive development in France, but that the quota cannot 'claim all the fame'. ${ }^{215}$ An additional point that needs to be made is that there are some countries in which, despite having chosen the path of quota legislation, female representation is still very low (even lower than the EU average). Spain (11.5\% in January 2012) and Italy (only 6.1\%) fall within this category of countries. One has to concede, though, that both percentages have increased compared to October 2010 when Spain (9.5\% on boards) were made up by women and there were $4.5 \%$ of women on Italian boards. ${ }^{216}$ The EU leader in female board representation, Finland, has reached a quota of more than $25 \%$ relying largely on 'soft measures' such as 'comply or explain' provisions in the Finnish Corporate Governance Code. ${ }^{217}$ Sweden has also been quite successful without implementing quotas. ${ }^{218}$ This has certainly contributed to the fact that quite a few voices in the German discussion have expressed their confidence that, given some time, existing (soft) measures will turn out to be sufficient. ${ }^{219}$ A final notable aspect in considering the success of quota legislation is the way the respective quotas have been reached. This question demands close scrutiny and shall be discussed subsequently below.

\section{Quota Legislation and Arguments For and Against its Adoption}

The suggestions that there are simply not enough women to fill $30 \%-40 \%$ of board positions, and that a mandatory quota of women would lead to inexperienced and under-qualified females being appointed to boards, are used as some of the strongest and most common arguments against adopting mandatory quota legislation. The argument then becomes that, eventually, the small number of qualified women available will lead to a small group of women taking on positions on multiple boards. ${ }^{220}$ Indeed, such a trend has developed in

\footnotetext{
${ }^{214}$ EC Press Release IP/12/213, above n 23, 2; Resolution on Women and Business Leadership, above n 61, M.3, 5.

${ }^{215}$ McKinsey \& Company, above n 67, 6 also expresses this as a general thought: '[Q]uotas cannot be credited with all the progress to date.'

${ }^{216}$ For all numbers see EC Press Release IP/12/213, above n 23, 5.

${ }^{217}$ See Resolution on Women and Business Leadership, above n 61, M.6.

${ }^{218}$ This is noted by McKinsey \& Company, above n 67, 6 .

${ }^{219}$ Weber-Rey, above n 180, 127; Kempter, above n 76, 220; Krieger, above n 73, 918. Similarly, the Chairman of the German Government's Commission on Corporate Governance, Klaus-Peter Müller, argued 'no rigid quota' quoted in Börsen-Zeitung, 14 June 2012 (Nr 112) 11.

${ }^{220}$ François-Poncet et al, above n 16, 454; Krieger, above n 73, 918.
} 
Norway. It is reported that around 70 female managers share 300 board positions among themselves, ${ }^{221}$ which has given rise to their nickname, 'golden skirts'. ${ }^{222}$ This development is viewed with scepticism, especially considering the potential conflicts of interest associated with membership on multiple boards. ${ }^{223}$

Many feel that, in the light of all this uncertainty, other measures should be granted preference over the adoption of quota laws. ${ }^{224}$ It is argued that a closer look at the causes of female underrepresentation is necessary, ${ }^{225}$ and that many women simply are not aspiring to work in top management. ${ }^{226}$ Rational and practical career choices and freedom of choice generally drive women's decisions to take up senior executive or board positions - not mandatory quotas. ${ }^{227}$ Increasing the availability of child care is a common example of measures aiming to change the situation. ${ }^{228}$ The European Commission has also stressed the importance of policies promoting work-life balance and encouraging the mentoring and training of women. ${ }^{229}$

Even under the assumption that there are currently too few qualified women, a considerable argument can be made for quota legislation: It might be appropriate to tackle the problem of female under-representation 'from the top' rather than 'from the bottom'. Women getting to top positions could subsequently serve as a role model for younger women. ${ }^{230}$ There might also be some truth to the idea that humans, when given the task of hiring or promoting a candidate, have a tendency to prefer those who resemble themselves, that is, men would generally be more likely to choose male candidates. ${ }^{231}$ This could be counteracted by putting more women into positions where they have at least an

${ }^{221}$ Balzter, above $n 5$.

${ }^{222}$ See Editorial, 'Most of the Women who Make up Norway’s “Golden Skirts” are Non-Execs', The Guardian (online), 1 July $2011<$ http://www.guardian.co.uk/business/2011/jul/01/norwaygolden-skirt-quota-boardroom>.

${ }^{223}$ Krieger, above n 73, 918.

${ }^{224}$ Federation of German Industry (BDI) and German Association of Chambers of Industry and Commerce (DIHK), Stellungnahme zum Gesetzesantrag des Landes Nordrhein-Westfalen (BRDrs 87/11) <http://www.dihk.de/themenfelder/recht-und-fairplay/rechtspolitik/nationalestellungnahmen/dihk-positionen-zu-nationalen-

gesetzesvorhaben/frauenquote/at_download/file?mdate=1326108611386>; Weber-Rey, above n $180,127$.

${ }^{225}$ Kempter, above n 76, 220.

${ }^{226}$ Weber-Rey, above n 180, 127.

${ }^{227}$ See McKinsey \& Company, above n 67, 8.

${ }^{228}$ Kempter, above n 77, 220; Krieger, above n 73, 918.

${ }^{229}$ EC Green Paper 2011, above n 35 [1.1.3].

${ }^{230}$ FöGAbUG, BR-Drucksache 87/11, above n 49, 3; Mayer, above n 46, 919.

${ }^{231}$ Mayer, above n 46, 919. 
equal say on who should be hired or promoted. It can hardly be disputed that by increasing the number of women in middle and senior management positions, it will over time increase the pool of experienced and competent women taking up senior executive and board positions. ${ }^{232}$

\section{Summary and Analysis}

There is no denying that women have been and still are under-represented on boards in most countries, and that is proven conclusively by all studies and available data. The reasons for the under-representation of women on boards are slightly more complex. In essence, there are those who argue that senior executive positions and board positions were (and still are) filled by the men who are the gatekeepers who make it impossible for more women to be appointed to those positions. The vicious cycle then is perpetuated because women are not given the opportunity to fill the positions, the pool of competent and experienced women remains small, providing another 'useful' excuse for not appointing more women to senior executive and board positions. There are many who argue this cycle should be broken, and some argue strongly that it can only be broken through mandatory gender quota legislation. Others argue that a 'one-size-fits-all' approach is not desirable and that board diversity and gender diversity on boards will be achieved through voluntary codes of corporate governance.

If one takes all the gender-sensitivity or emotion out of the debate, there are just too many reasons that suggest that board diversity, and gender-diversity in particular, is the right and 'bright' thing to strive for. This is true even though the 'business case' for both board diversity generally, and gender diversity on boards in particular, has never been proven convincingly.

\section{Concluding Remarks}

The research undertaken shows that in Europe, Australia and Germany, the debate on board diversity is seen as wider than just a debate on gender diversity. Cultural, race, age, stakeholder and nationality diversity also form part of the debate. In several European countries, as well as in Australia and in South Africa, efforts are being made through voluntary codes of conduct to strive for board diversity. Gender diversity is a particular focus in all jurisdictions.

It is not difficult to predict that in Europe, Australia and South Africa there will be more women appointed to senior executive positions and on boards in future.

\footnotetext{
${ }^{232}$ Krieger, above n 73, 918.
} 
What the actual effect of that will be from a business point of view is impossible to predict. However, that women will have a bigger say in the corporate world in, say, five years' time, is beyond dispute. That will be the case, irrespective of whether the problem of under-representation of women on boards is addressed through mandatory gender quota legislation, through targets or simply through voluntary codes of corporate governance. In fact, this prediction brings with it a huge responsibility on women to live up to the expectations that improved gender balance will lead to improvements. However, what exactly the improvements will be and whether the business case for appointing more women in senior executive positions and on boards will emerge clearly, is something that only time will tell. 